\title{
Influence of temperature on the antioxidant responses and lipid peroxidation of two species of tadpoles (Rhinella schneideri and Physalaemus nattereri) exposed to the herbicide sulfentrazone (Boral 500SC ${ }^{\circledR}$ )
}

\author{
Juliane Silberschmidt Freitas ${ }^{\mathrm{a}}$, Fabrício Barreto Teresa ${ }^{\mathrm{b}}$, Eduardo Alves de Almeida ${ }^{\mathrm{c}_{*}}$ \\ a Graduate Program in Animal Biology, Department of Chemistry and Environmental Sciences, Universidade Estadual Paulista "Júlio de Mesquita Filho", Cristóvão \\ Colombo, 2265, 15054-000 São José do Rio Preto, SP, Brazil \\ b Universidade Estadual de Goiás, Campus de Ciências Exatas e Tecnológicas, BR 153 n 3105 - Fazenda Barreiro do Meio, CEP: 75132-903 Anápolis, GO, Brazil \\ ${ }^{\mathrm{c}}$ Department of Natural Sciences, Fundação Universidade Regional de Blumenau, Av. Antonio da Veiga 140, Itoupava Seca, 89030-903 Blumenau, Santa Catarina, Brazil
}

\section{A R T I C L E I N F O}

\section{Keywords:}

Amphibians

Sulfentrazone

Temperature

Biochemical biomarkers

Oxidative stress

\begin{abstract}
A B S T R A C T
Amphibians can experience large temperature fluctuations in their habitats, especially during the larval stage, when tadpoles are restricted to small and ephemeral ponds. Changes in water temperature can alter development, metabolism and behaviour of cold-blooded animals but also the toxicokinetics of chemicals in the environment. In Brazil, pesticides application is intensified during the rainy season, which is the period of reproduction for many amphibian species. We evaluated here the influence of temperature $\left(28,32\right.$, and $\left.36^{\circ} \mathrm{C}\right)$ on the toxicity of the herbicide sulfentrazone (Boral ${ }^{\circledR} \mathrm{SC}$ ) in tadpoles of Physalaemus nattereri and Rhinella schneideri, by analysis of oxidative stress biomarkers. Exposure of tadpoles to sulfentrazone altered the antioxidant enzymes activities and induced lipid peroxidation with temperature-associated responses. Catalase, superoxide dismutase and glucose-6-phosphate dehydrogenase (G6PDH) were impaired by combined effect of temperature and sulfentrazone in both species. G6PDH was increased in most groups exposed to $36^{\circ} \mathrm{C}$. Biotransformation enzyme glutathione- $S$-transferase had more evident alterations in $P$. nattereri at higher temperatures and changes in $t \mathrm{GSH}$ contents presented different patterns between the species. Lipid peroxidation was particularly induced in tadpoles of $P$. nattereri. Integrated biomarker response (IBR) index indicated a synergic effect of temperature and sulfentrazone for tadpoles of $P$. nattereri, while the IBR was mainly influenced by temperature in $R$. schneideri. Our study showed that temperature modulates biochemical responses in tadpoles exposed to sulfentrazone with a species-specific pattern. These findings imply that the effects of abiotic factors should be taken into account to evaluate the real risks of exposure of amphibians to commonly used pesticides.
\end{abstract}

\section{Introduction}

Increased agriculture activity in Brazil has caused extensive impact on several natural ecosystems and non-target organisms, especially due to the intensified use of pesticides. Brazil is the largest consumer of pesticides in the world, and sugarcane is one of the main crops contributing to the expansion of cultivated areas in recent years (UNICA, 2015). In south-eastern Brazil, the state of São Paulo is responsible for the usage of approximately $20 \%$ of all Brazilian pesticides and has the highest rates of conversion of natural habitats to agricultural land (IPT, 2000). Several species of amphibians have been recorded in this area (Bernarde and Kokubum, 1999; Prado et al., 2008; Provete et al., 2011) and many of them are distributed in areas common to agriculture practice. Considering the accelerated expansion of sugarcane in Brazil, mainly due to its use in biofuel production, there is a great concern that several amphibian species are threatened by exposure to local pesticides.

Sulfentrazone (2',4'-dichloro-5-(4-difluoromethyl-4,5-dihydro-3methyl-5-oxo-1H-1,2,4-triazol-1-yl) methanesulfonanilide) is an herbicide widely used in sugarcane crops in Brazil and other areas of the world. It is also applied in crops of great commercial importance, such as soy, coffee, citrus and eucalyptus (Embrapa, 2013). Sulfentrazone inhibits protoporphyrinogen oxidase, an important enzyme in chlorophyll biosynthesis, causing extreme dehydration of foliage due to the loss of membrane integrity (Dayan and Watson, 2011). Little is known about the transport and fate of sulfentrazone in the environment, however it is known that its first route of dissipation includes microbial degradation (Hatzios, 1998). This herbicide belongs to the aryl

\footnotetext{
* Corresponding author

E-mail address: edualves1976@hotmail.com (E.A. de Almeida).
} 
triazolinones group and is considered a potential contaminant due to its long residual effect in soil (110-280 days) and relatively high water solubility (Hirata, 2010; Melo et al., 2010). Following application to soil, sulfentrazone can runoff into surface water, potentially leading to negative effects to aquatic organisms. Concentrations of sulfentrazone found in freshwater environments such as rivers, lagoons or even temporary ponds used by amphibians as a transitory environment during larval development, are still unknown due to a lack of studies in the literature. However, evidence has shown that sulfentrazone has been found in both soil and water in agriculture areas of Sao Paulo (Dutra De Armas et al., 2005). Concentrations of this and other herbicides may be particularly high in small and ephemeral ponds used by amphibians as habitats, since they are formed by flooding of soil during the rainy season.

Larval stages of anurans are especially susceptible to pesticides and other chemical compounds (Greulich and Pflugmacher, 2003) because tadpoles are strictly aquatic and have high skin permeability (Yan et al., 2008). In tropical areas with well-defined seasons, the reproduction of most amphibian species, and the subsequent occurrence of tadpoles, is restricted to the rainy season due to the availability of water (Mcdiarmid and Altig, 1999; Provete et al., 2011). It is also during this season that the contamination of lakes and streams as result of herbicide application is usually increased, especially due to the use of pre-emergent herbicides, such as sulfentrazone, which are better absorbed in moist soils. In Brazil, the rainy season occurs predominantly during the summer and is accompanied by the highest temperature averages of the year. Due to the small volume of water in ephemeral ponds, the water temperature is easily elevated, increasing the average temperatures and the daily thermal fluctuations. Previous studies have shown that the water temperature can exceed $40{ }^{\circ} \mathrm{C}$ during the summer in ponds where several species of tadpoles have been found in Brazil (Freitas et al., 2016). The deforestation in nearby areas of amphibian habitats and the loss of vegetation has also favored the increase of solar incidence in these small ponds, thus contributing to the water heating. Therefore, it should be considered that Neotropical tadpoles inhabiting agricultural areas are not only threatened by pesticide exposure, but also by the interaction effects of these substances and the environmental temperature variations.

Temperature is mentioned as one of the main abiotic factors influencing the toxicity of chemical compounds in the environment (Hooper et al., 2013; Noyes et al., 2009). Chemical and biological reactions become faster in warmer waters, and therefore, the effect of a toxic agent may be more pronounced at higher temperatures (Middlebrooks et al., 1973). For poikilothermic animals, thermal variation of the environment is directly translated into the variation of the physiological performance (Fontenot and Lutterschmidt, 2011). Temperature affects virtually all physiological aspects of amphibians, including digestion, vision, locomotion, growth and metabolism (Rome, 2007; Gatten et al., 1992). Thus, changes in environmental temperature can interfere with many natural biological responses in different species, making the organisms more susceptible to the action of xenobiotics (Blaustein et al., 2010; Blaustein and Kiesecker, 2002; Moe et al., 2013). Previous studies have shown that temperature plays an important role in the toxicity of several pesticides for amphibians (Boone and Bridges, 1999; Freitas et al., 2016; Hammond et al., 2015). For example, the mortality of tadpoles of Rana clamitans exposed to the insecticide carbaryl was increased at lower concentrations when animals were exposed to higher temperatures (Boone and Bridges, 1999). Exposure of tadpoles of the American bullfrog (Lithobates catesbeianus) to the herbicide diuron and its metabolite 3,4-DCA also showed that thyroidogenic effects of both compounds were more pronounced in animals exposed at higher temperatures (Freitas et al., 2016).

Despite the increasing number of studies exploring the effects of temperature on the toxicity of chemical compounds (Bao et al., 2008; Hooper et al., 2013; Moe et al., 2013; Noyes et al., 2009; Rohr and
Palmer, 2005; Schiedek et al., 2007), the data collected to date are not comprehensive enough to routinely support integrated risk assessments for biological communities. Cold-blooded animals, such as amphibians, have inter- and intra-specific variations in their thermal tolerances (Katzenberger et al., 2012), so studying the toxicity of a chemical at one standard temperature may not be adequate to estimate negative effects to different species in environmental systems. Biomarkers of oxidative stress have been widely used to assess negative effects of pesticides on amphibians (e.g., Dornelles and Oliveira, 2014; Gripp et al., 2017; Stefani Margarido et al., 2013), since they may provide valuable information about amphibian health status (Peltzer et al., 2013). They are also relevant to assess the effects of thermal stress on poikilotherms, since temperature is an important factor affecting antioxidant enzymes in these organisms (e.g., Bagnyukova et al., 2003; Madeira et al., 2013; Vinagre et al., 2012). So far, no studies have investigated the effects of sulfentrazone on tadpoles and very few studies report its effects in nontarget organisms, especially considering temperature variations. Therefore, this study aimed to investigate the effects caused by the interaction between temperature and the herbicide sulfentrazone in two native species of tadpoles in Brazil, Physalaemus nattereri and Rhinella schneideri, using oxidative stress markers. For this, we evaluated enzymes involved in antioxidant responses, including activities of superoxide dismutase (SOD), catalase (CAT), glucose-6-phosphate dehydrogenase (G6PDH), the biotransformation enzyme glutathione-S transferase (GST) and levels of total glutathione ( $t \mathrm{GSH})$. Lipid peroxidation was also evaluated by measuring the levels of malondialdehyde (MDA). Biological responses in tadpoles of both species were assessed based on individual biomarkers and on an integrative index, the integrated biomarker response (IBR, sensu Beliaeff and Burgeot, 2002). We hypothesized that a temperature increase may enhance the effects of sulfentrazone; with alterations to antioxidant defence systems, and induction of lipid peroxidation as a response of increased generation of reactive oxygen species (ROS) by stimulation of the metabolic processes in both species. Also, sulfentrazone may cause distinct effects in different tadpole species, indicating that they can be distinctly susceptible to negative effects caused by this herbicide.

\section{Material and methods}

\subsection{Animals}

Laboratory tests were conducted using two species of tadpoles, since species- or family-level sensitivity has been increasingly considered for use in laboratory tests evaluating toxicity of pesticides to amphibian populations (Egea-Serrano et al., 2012; Relyea, 2005; Shinn et al., 2008; Snodgrass et al., 2008). Physalaemus nattereri (Leiuperidae) and Rhinella schneideri (Bufonidae) are common anuran species with a wide geographical distribution in the northwest of São Paulo, Brazil. They can be found in different habitats, including pastures and sites of intense agriculture (Provete et al., 2011). Tadpoles of the selected species have different habitats in water bodies, with $P$. nattereri preferring benthic habitats and $R$. schneideri neustonic habitat (Prado et al., 2008; Provete et al., 2011).

\subsection{Tadpole collection and acclimation}

Spawns of the anurans $P$. nattereri and $R$. schneideri were collected in temporary ponds in non-agricultural areas in the region of Sao Jose do

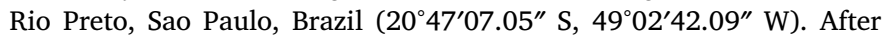
hatching, the larvae were maintained in the laboratory under ideal conditions of temperature $\left(28^{\circ} \mathrm{C}\right)$ and $\mathrm{pH}(7.5-8.0)$ in aerated aquariums during four weeks, until they reached stages 27-30 (Gosner, 1960), just before the development of legs. The animals were collected under license n.18573-1, authorized by the Brazilian Institute of Environment and Renewable Natural Resources (IBAMA). 


\subsection{Experimental design}

\subsubsection{Temperature treatment}

Aquariums containing dechlorinated water were heated to three different temperatures: 28,32 and $36^{\circ} \mathrm{C}$. Temperatures were maintained by autoregulating thermostats in $5 \mathrm{~L}$ aquariums placed in a $100 \mathrm{~L}$ "water bath". The temperature of the tanks and individual aquariums had their values recorded daily to observe possible variations during the experimental period. Temperature values used in this study were based on Freitas et al. (2016), which recorded the water temperature in 5 natural ponds in which tadpoles of $R$. schneideri and $P$. nattereri are frequently found. These data were recorded during the summer, which coincides with the rainy season and reproduction for most neotropical frogs.

\subsubsection{Chemical treatments}

Tadpoles of $P$. nattereri and $R$. schneideri were exposed to $0.01,0.05$ and $0.1 \mathrm{mg} / \mathrm{L}$ of sulfentrazone (2',4'-dichloro-5-(4-difluoromethyl-4,5dihydro-3-methyl-5-oxo-1H-1,2,4-triazol-1-yl) methanesulfonanilide), using the commercial herbicide Boral $^{\oplus 500 S C}$ (sulfentrazone $500.00 \mathrm{~g} /$ $\mathrm{L}-50,0 \% \mathrm{~m} / \mathrm{v}$ ). Tadpoles of each species were exposed separately to each concentration at temperatures of 28,32 and $36{ }^{\circ} \mathrm{C}$ for three and eight days. Concentrations of sulfentrazone were based on the product concentration recommended for use in the field (Martinez et al., 2010) and in studies reporting possible concentrations in water after leaching that may be available in aquatic habitats (Thorngren et al., 2016). The experimental groups consisted of five replicates $(n=5)$ containing six tadpoles in each aquarium. The tadpoles were placed into the aquariums, and the water temperature was gradually adjusted during the first day to avoid thermal shock. Then, sulfentrazone was added at nominal concentrations as described above. The herbicide was dissolved in a stock solution of $1 \mathrm{~mL}$ of water and then added to the aquariums. A control group containing no contaminants was provided for each temperature and experiment duration. Aquariums were constantly aerated at a $\mathrm{pH}$ of $8.00 \pm 0.4$ and using a light-dark cycle of $12-12 \mathrm{~h}$. The water was renewed every two days to ensure the original concentration of the contaminant and the dissolved oxygen, $\mathrm{pH}$ and ammonia were quantified for the same period. No significant variations were observed in these parameters among treatments during the experiments (dissolved oxygen 6.5-7.1 mg/L, pH 7.2-8.3). The animals were fed every two days with commercial feed for tropical fish in minimum quantities (200 $\mathrm{mg}$ ) avoiding accumulation in the aquariums. At the end of the experiment, the tadpoles were removed from the tanks and euthanized by direct immersion in liquid nitrogen. All the procedures were performed in accordance with the Ethics Committee on Animal Use in Research of the São Paulo State University (CEUAIBILCE/UNESP No. 086/2013).

\subsection{Analysis}

\subsubsection{Morphological analysis}

Effects on growth (snout-vent length (SVL) and body weight) and development (Gosner, 1960) were evaluated individually in tadpoles from both species after three and eight days of exposure at different temperatures.

\subsubsection{Preparation of samples}

For the enzymatic measurements, two tadpoles of each replicate $(n=10)$ were entirely and individually homogenized at a ratio of 1:4 (weight:volume) in cold $\left(4^{\circ} \mathrm{C}\right) 20 \mathrm{mM}$ Tris-HCl homogenization buffer (Tris-HCl $20 \mathrm{mM}$, EDTA $1 \mathrm{mM}$, DL-dithiothreitol (DTT) $1 \mathrm{mM}$, sucrose $0.5 \mathrm{M}$, KCL $0.15 \mathrm{M}$, phenylmethylsulfonyl fluoride (PMSF) $1 \mathrm{mM}$ ), $\mathrm{pH} 7.4$, and centrifuged for $30 \mathrm{~min}$ at $9000 \mathrm{~g}$ at $4{ }^{\circ} \mathrm{C}$. The supernatant fraction was collected and centrifuged again for $1 \mathrm{~h}$ at 50,000g. The second supernatant fraction was collected and stored at $-80{ }^{\circ} \mathrm{C}$ for subsequent evaluation.
Lipid peroxidation was assessed by the measurements of MDA levels. For this analysis, two tadpoles of each replicate $(n=10)$ were entirely homogenized at a ratio of 1:3 (weight:volume) in $0.1 \mathrm{M}$ Tris$\mathrm{HCl}$ buffer, $\mathrm{pH}$ 8.0. After homogenization, $300 \mu \mathrm{L}$ of thiobarbituric acid (TBA, Sigma-Aldrich, Germany) diluted in $0.4 \% \mathrm{HCl}$ were added to the sample. The mixture was heated at $90{ }^{\circ} \mathrm{C}$ for $40 \mathrm{~min}$, and the reaction product was extracted with $1.0 \mathrm{~mL}$ of $n$-butanol (Sigma-Aldrich, USA). After this procedure, the $n$-butanol fraction was injected $(10 \mu \mathrm{L})$ into a High-Performance Liquid Chromatography system (Shimadzu Corporation, Kyoto, Japan). The chromatogram was monitored for $10 \mathrm{~min}$ and peaks were identified and quantified using LAB Solutions 5.71 software (Shimadzu Corporation).

For $t \mathrm{GSH}$ analysis, two tadpoles of each replicate $(n=10)$ were entirely and individually homogenized at a ratio of $1: 9$ (weight:volume) in a cold $\left(4^{\circ} \mathrm{C}\right)$ solution of perchloric acid (PCA) $0.5 \mathrm{M}$ and centrifuged for $5 \mathrm{~min}$ at $15,000 \mathrm{~g}$ at $4{ }^{\circ} \mathrm{C}$. Supernatants were collected and neutralized with a solution of potassium phosphate $0.1 \mathrm{M}(0.1 \mathrm{M}, \mathrm{pH} 7.0)$ and then centrifuged at $15,000 \mathrm{~g}$ for $2 \mathrm{~min}$ at $4{ }^{\circ} \mathrm{C}$.

\subsubsection{Antioxidant enzyme measurements}

Analyses of CAT were performed in a Thermo Evolution 300 spectrophotometer with a dual beam, and capacity for seven cuvettes. The activities of GST, G6PDH and SOD were performed on a Victor ${ }^{\mathrm{TM}}$ $\times 3$ microplate reader (Perkin Elmer ${ }^{\circledR}$ ). The activity of all enzymes was evaluated at the respective temperatures $\left(28,32\right.$ and $\left.36^{\circ} \mathrm{C}\right)$ at which the animals were subjected to treatments.

CAT activity was measured using the method described by Beutler (1975), which monitors the rate of decomposition of hydrogen peroxide by the enzyme at $240 \mathrm{~nm}$ for $1 \mathrm{~min}$. Specific activity was expressed as $\mathrm{U} \mathrm{mg}$ of protein ${ }^{-1}$. The assays were performed using Tris- $\mathrm{HCl}$ buffer (1 M, pH 8.0) with $5 \mathrm{mM}$ EDTA and $\mathrm{H}_{2} \mathrm{O}_{2}$ as the substrate.

GST activity was measured using the method described by Habig et al. (1974), which monitors the formation of the conjugate of 1chloride-2,4-dinitrobenzene (CDNB) with reduced glutathione (GSH) catalysed by GST in the sample for $1 \mathrm{~min}$ at $340 \mathrm{~nm}$. Specific activity was expressed as $\mathrm{U} \mathrm{mg}$ of protein ${ }^{-1}$. The final volume of the assay was $110 \mu \mathrm{L}$, which contained potassium phosphate buffer (0.2 M, pH 6.5), $1 \mathrm{mM}$ CDNB (dissolved in $1.0 \mathrm{~mL}$ of absolute ethanol), $1 \mathrm{mM} \mathrm{GSH}$, and the sample.

The enzymatic assay of G6PDH (Glock and McLean, 1953) measured the formation of nicotinamide adenine dinucleotide phosphate $(\mathrm{NADPH})$ at $340 \mathrm{~nm}$ for $1 \mathrm{~min}$. The assay consists of the reduction of $\mathrm{NADP}+$ to NADPH by the G6PDH using glucose-6-phosphate (G6P) as the substrate. The assay had a final volume of $205 \mu \mathrm{L}$, which contained Tris-HCl buffer (0.1 M, pH 7.4), $\mathrm{MgCl}_{2}, \mathrm{NADP}+$, G6P and the sample. The reference blank did not contain G6P. Specific activity was expressed as $\mathrm{mU} \mathrm{mg}$ of protein $^{-1}$.

SOD activity was measured using SOD Assay Kit-WST (Sigma, Aldrich) by utilizing Dojindo's highly water-soluble tetrazolium salt, WST-1 (2-(4-Iodophenyl)-3-(4-nitrophenyl)-5-(2,4-disulfophenyl)-2Htetrazolium, monosodium salt) that produces a water-soluble formazan dye upon reduction with a superoxide anion. The rate of the reduction with $\mathrm{O}_{2}$ is linearly related to the xanthine oxidase activity, and is inhibited by SOD. Since the absorbance at $440 \mathrm{~nm}$ is proportional to the amount of superoxide anion, the SOD activity as an inhibition activity was quantified by measuring the decrease in the colour development at $440 \mathrm{~nm}$.

\subsubsection{Determination of total GSH levels ( $t G S H)$}

$t \mathrm{GSH}$ contents were assessed by the Tietze (1969) protocol, adapted by Sies (2003). The total amount of GSH was measured based on the reaction between GSH and DTNB (5,5'-Dithiobis(2-nitrobenzoic acid)), which produces the conjugate GS-TNB and the yellow TNB (5-thio-2nitrobenzoic acid) anion that can be detected at $412 \mathrm{~nm}$. The rate of TNB production is proportional to the amount of GSH in the extract. Thus, the more GSH in the sample, the more TNB is formed, which is 
monitored at $412 \mathrm{~nm}$ for $2 \mathrm{~min}$. A recycling reaction catalysed by glutathione reductase in the presence of NADPH was also coupled to the assay, regenerating 2GSH from the GSSG formed previously by the reaction with DTNB. This enables a continuous production of TNB, which is proportional to the total GSH (GSH + GSSG) in the sample. The concentration in $\mu \mathrm{mol} \mathrm{GSH} \mathrm{g}^{-1}$ of tissue in the sample was calculated based on a standard curve with known amounts of GSH, obtained in the assay by the change in absorbance per minute $(\Delta \mathrm{A})$. Analyses of GSH were performed in a Thermo Evolution 300 spectrophotometer with a dual beam and capacity for seven cuvettes.

\subsubsection{MDA measurements}

MDA levels were evaluated following the method described by Almeida (2003) using a high performance liquid chromatography (HPLC) system (ESA, USA) coupled to a UV-Vis detector (526, ESA, USA) to analyse the product formed between malondialdehyde (MDA) and TBA. The chromatographic column used in analysis was a Shimadzu C18 column $(150 \times 4.6 \mathrm{~mm}, 5 \mu \mathrm{m})$, using $50 \mathrm{mM}$ potassium phosphate solution at $\mathrm{pH} 7.0$ as the mobile phase, with $40 \%$ methanol, and at a flow rate of $1.0 \mathrm{~mL} / \mathrm{min}$.

\subsubsection{Protein quantification}

Proteins were quantified using the Bradford (1976) protocol with Coomassie Brilliant Blue G-250 in an acidic solution. The absorbance values were determined at $595 \mathrm{~nm}$, and the results were compared to the analytical curve prepared with bovine serum albumin (BSA) as the standard.

\subsubsection{Integrated biomarker response (IBR)}

Biomarker responses were also evaluated in an integrated approach by using the integrated biomarker response (IBR) (Beliaeff and Burgeot, 2002). This index integrates the responses of different biomarkers into a single measure. For the IBR calculation, individual biomarker values were standardized across samples (z-score) and resulting scores were rescaled by summing the modulus of the minimal value observed for all samples and each biomarker, so the minimal scores become zero. Activation response of the expected biomarker was assumed for this calculation. The IBR value corresponds to the area of the radar chart, in which each radius represents the score of a given biomarker (Beliaeff and Burgeot, 2002). However, as the biomarker sequence in the radar chart influences the IBR value (Devin et al., 2014), we calculated IBR values for each possible circular sequence of the six biomarkers (120 sequences for each sample in our case) (Devin et al., 2014). The final IBR for each sample was the median of the IBR values calculated in all possible sequences.

IBR was calculated considering data from each species separately, thus allowing a comparison between those data. Because biochemical analysis were performed by using different individuals from each aquarium, we calculated IBR using each aquarium as a sample $(n=5)$.

\subsubsection{Statistical analysis}

The presence of outliers was evaluated and the normality and homogeneity of the data was checked by the Shapiro-Wilk and Levene's tests, respectively. Logarithmic transformation $[\log (x+1)]$ was performed in those data that did not meet the assumptions of normality and homogeneity of variance. Two-way analysis of variance (ANOVA 2way), followed by the Tukey post hoc test were used to identify statistical differences (antioxidant enzyme activity, MDA levels and effects on growth - length and weight). This test was used to evaluate the individual effects of temperature $\left(28,32\right.$ and $\left.36 \mathrm{C}{ }^{\circ} \mathrm{C}\right)$ and chemical treatments (concentrations of sulfentrazone at $0.01,0.05$ and $0.1 \mathrm{mg} /$ L), and the interaction effects between the temperature and chemical treatments. If data were still considered non-parametric after logtransformation, the Kruskal-Wallis of multiple comparisons test was performed. Non-exposed tadpoles at $28^{\circ} \mathrm{C}$ were assumed as the control group for comparison of interaction effects of temperature and chemical exposure, since the animals were acclimatized at this temperature and this group had no influence of either thermal stress or chemical exposure. To assess whether there were differences between the stages of development of the tadpoles, the G test was performed with Yates' correction (Sokal and R.J., 1995). Statistical analysis was conducted using R version 2.11.1 (R Development Core Team, 2010) and STATISTICA (StatSoft). Values of $P<0.05$ were considered as a reference to assign statistical significance (Zar, 1999).

\section{Results}

\subsection{Effects on tadpole mortality, growth and development}

Mortality was not observed in any of the experimental groups for either species. Effects on growth (snout-vent length (SVL) and weight) were assessed at the end of the treatments. For P. nattereri, biometric analysis showed no changes on growth and length of tadpoles for any treatment after three days of exposure (Table S1). Stages of development were also unchanged after three days for any treatment $(P=0.47)$ (Table S3). After eight days of exposure, untreated tadpoles maintained at $36{ }^{\circ} \mathrm{C}$ presented higher weight $(P=0.043)$ and body length $(P=0.016)$ than those maintained at $28^{\circ} \mathrm{C}$ (Table S1). Chemical treatments caused no effects on weight or body length of tadpoles at any other temperature. Stage of development was accelerated in tadpoles exposed to $0.05 \mathrm{mg} / \mathrm{L}$ at $32{ }^{\circ} \mathrm{C}$ (stages Gs31-36) compared to the control group at the same temperature (stages Gs29-34) $(P=0.020)$ after eight days. This group presented $20 \%$ of tadpoles at Gs35 and 30\% at Gs36, while any tadpoles of control overtook Gs34 (Table S4).

In R. schneideri, temperature had no single effect on the weight and length of tadpoles for both experimental periods. Sulfentrazone also had no effects on weight $(P=0.298)$ or length $(P=0.764)$ of tadpoles after three days of exposure at any temperature (Table S2). After eight days, no effects on weight were observed; however, tadpoles exposed to $0.1 \mathrm{mg} / \mathrm{L}$ at $32^{\circ} \mathrm{C}$ were larger than animals of the control group assessed at $28{ }^{\circ} \mathrm{C}(P=0.034)$ and those exposed to the same concentration $(0.1 \mathrm{mg} / \mathrm{L})$ at $28^{\circ} \mathrm{C}(P=0.009)$ and $36^{\circ} \mathrm{C}(P=0.01)$ (Table S2). Stages of development were unaffected by treatments in $R$. schneideri $(P=0.60)$ (Tables S5 and S6).

\subsection{Antioxidant enzyme and lipid peroxidation}

\subsubsection{P. nattereri}

Temperature had isolated effects on antioxidant enzymes in tadpoles of $P$. nattereri not exposed to sulfentrazone. G6PDH activity was lower in animals of the control group at $32{ }^{\circ} \mathrm{C}$ than the control animals at $28{ }^{\circ} \mathrm{C}$ after three days $(P=0.007)$. Similarly, $t \mathrm{GSH}$ was lower in animals maintained at $32{ }^{\circ} \mathrm{C}$ than those kept at $28^{\circ} \mathrm{C}(P=0.017)$ (Fig. 1). GST was increased in animals maintained at $36^{\circ} \mathrm{C}$ compared to the control group at $28{ }^{\circ} \mathrm{C}$ for both experimental periods of three $(P=0.005)$ and eight days $(P=0.034)$ (Fig. 2). After eight days, SOD activity was diminished in tadpoles of the control group at $32{ }^{\circ} \mathrm{C}$ compared to control at $28^{\circ} \mathrm{C}(P=0.013)$ (Fig. 2). CAT activity was not affected by temperature $(P>0.05)$.

Treatment with sulfentrazone at different thermal conditions also changed the antioxidant activity of the enzymes in E. nattereri tadpoles. After three days of exposure, treatment with sulfentrazone at $28{ }^{\circ} \mathrm{C}$ increased CAT activity in animals exposed to $0.1 \mathrm{mg} / \mathrm{L}$ compared to the control at the same temperature $(P=0.012)$. GST activity was induced in animals exposed to all concentrations of sulfentrazone at $28^{\circ} \mathrm{C}$ ( $P=0.036, P<0.001, P<0.001$, respectively). $t \mathrm{GSH}$ levels were also elevated in tadpoles exposed to $0.05 \mathrm{mg} / \mathrm{L}$ compared to the control group ( $P=0.043)$. SOD and G6PDH activities were unchanged following sulfentrazone treatments at $28{ }^{\circ} \mathrm{C}(P>0.05)$. At $32{ }^{\circ} \mathrm{C}$, animals exposed to $0.01 \mathrm{mg} / \mathrm{L}$ of sulfentrazone had lower CAT activity than those exposed to $0.1 \mathrm{mg} / \mathrm{L}(P<0.001)$. Interaction effects with 


\section{P. nattereri $\square$ Control \\ 3 days-exposure $\square 0.05 \mathrm{mg} / \mathrm{L}$ \\ $0.1 \mathrm{mg} / \mathrm{L}$}

CAT

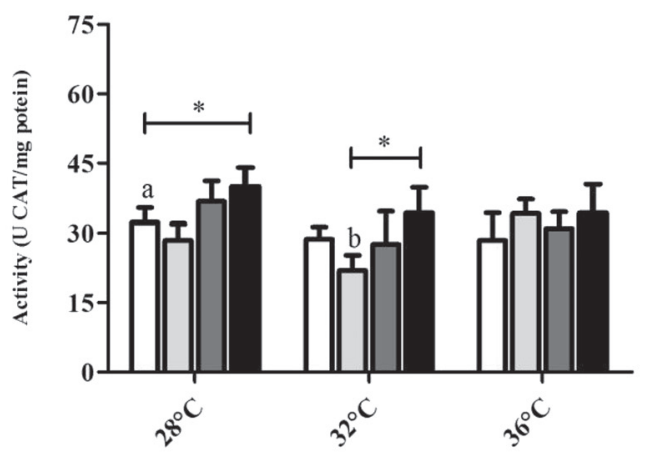

G6PDH

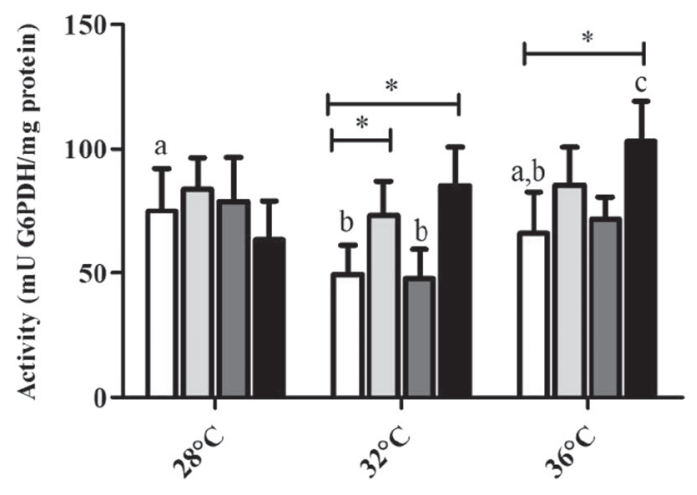

tGSH

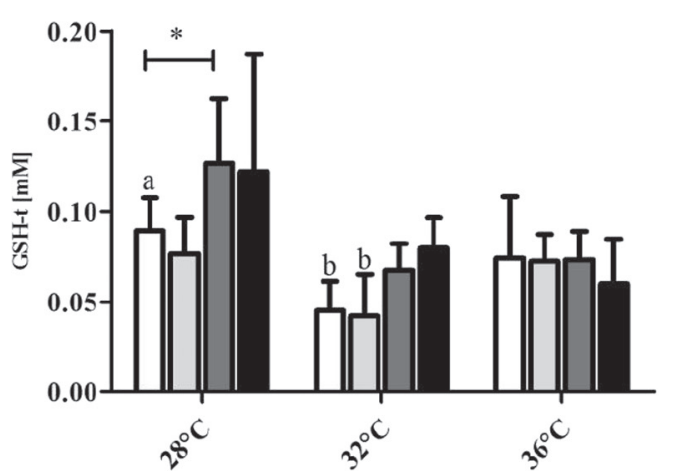

SOD

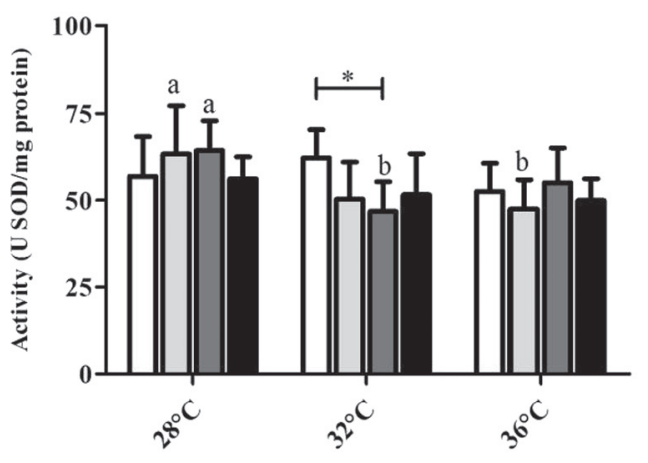

GST

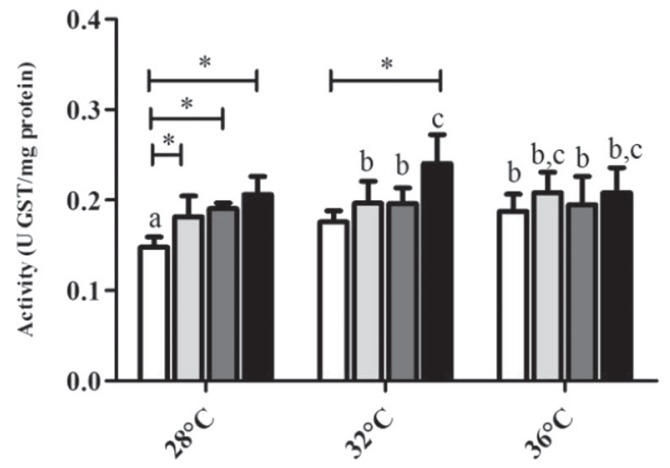

MDA

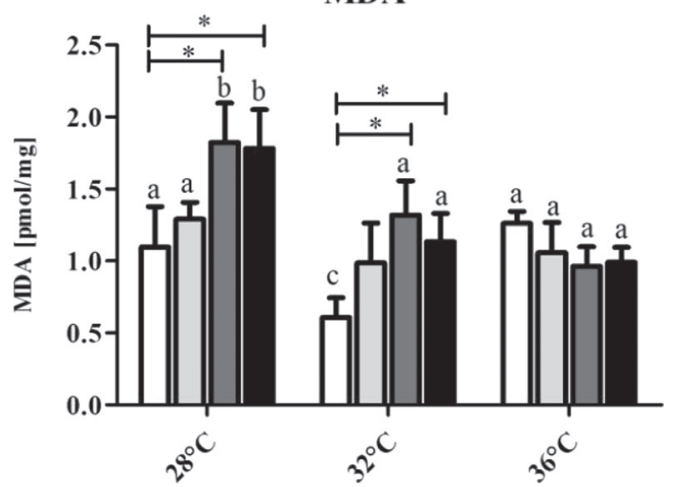

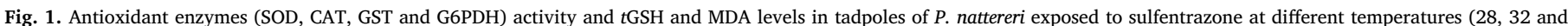

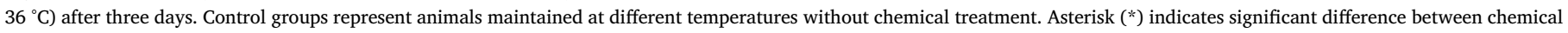
treatments $(0.01,0.05$ and $0.1 \mathrm{mg} / \mathrm{L})$ at the same temperature. Different letters indicate statistical significance $(P<0.05)$ among relevant groups treated at different temperatures.

temperature also diminished CAT activity in tadpoles exposed to $0.01 \mathrm{mg} / \mathrm{L}$ at $32{ }^{\circ} \mathrm{C}$ compared to the control at $28^{\circ} \mathrm{C}(P=0.0002)$. SOD was decreased in tadpoles exposed to $0.05 \mathrm{mg} / \mathrm{L}$ of sulfentrazone at $32{ }^{\circ} \mathrm{C}$ compared to the control group at the same temperature $(P=0.039)$. Increases in G6PDH activity were observed in animals treated with sulfentrazone at 0.01 and $0.1 \mathrm{mg} / \mathrm{L}$ at $32{ }^{\circ} \mathrm{C}$ compared to the respective control $(P=0.020 ; P=0.00013$, respectively), with higher induction of G6PDH in the highest concentration. An increase in GST was only found in animals treated at the higher concentration at $32{ }^{\circ} \mathrm{C}(P=0.0001)$ after three days. At $36{ }^{\circ} \mathrm{C}$, treatments with sulfentrazone had no effects on CAT or SOD activities, or on $t \mathrm{GSH}$ levels.
Animals treated with $0.1 \mathrm{mg} / \mathrm{L}$ at $36^{\circ} \mathrm{C}$ presented an increase on G6PDH activity compared to control animals at the same temperature $(P<0.001)$, and to the control at $28^{\circ} \mathrm{C}(P=0.002)$, showing an interaction effect at $36^{\circ} \mathrm{C}$. An interactive effect was also observed for GST $(P=0.005)$, which was increased in all groups treated at $36{ }^{\circ} \mathrm{C}$ compared to the control at $28{ }^{\circ} \mathrm{C}(P<0.001)$ (Fig. 1).

After eight days of exposure, sulfentrazone caused no effects on antioxidant enzymes of animals treated at $28^{\circ} \mathrm{C}$, except for G6PDH that had its activity increased 2.6-fold in tadpoles exposed to $0.05 \mathrm{mg} / \mathrm{L}$ compared to the control group $(P=0.00012)$ (Fig. 2). At $32{ }^{\circ} \mathrm{C}, \mathrm{G} 6 \mathrm{PDH}$ activity was increased in animals treated at concentrations of $0.01,0.05$ 


\section{Control \\ P. nattereri $\square 0.01 \mathrm{mg} / \mathrm{L}$ \\ 8 days-exposure $0.1 \mathrm{mg} / \mathrm{L}$}

CAT

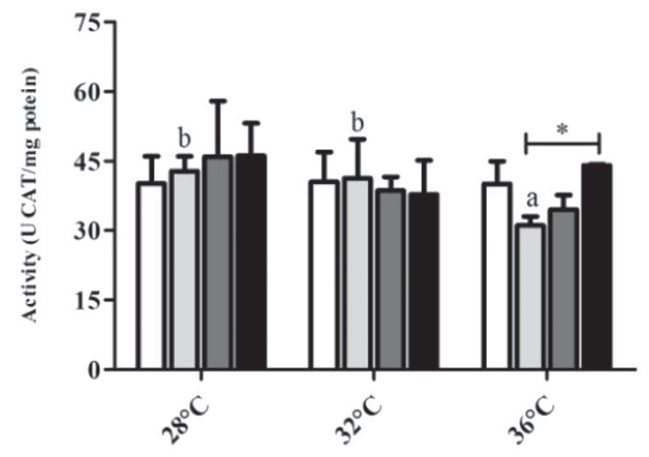

G6PDH

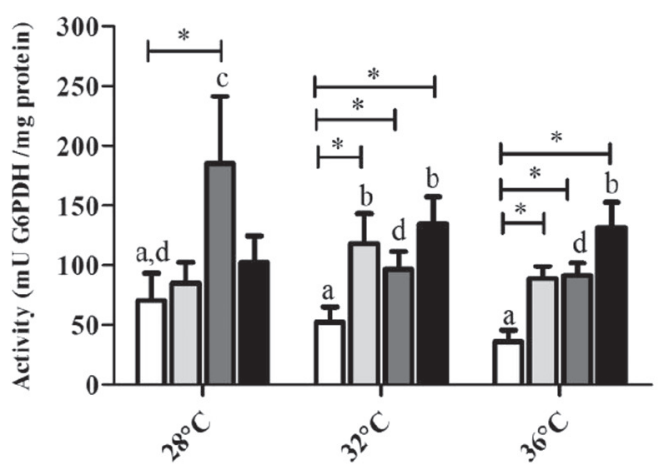

tGSH

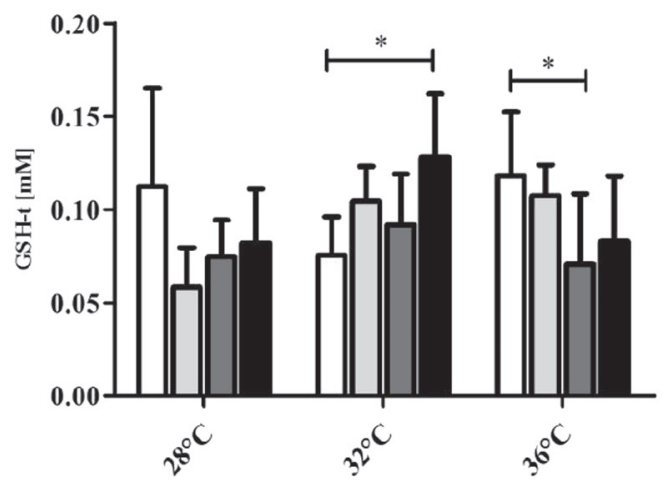

SOD
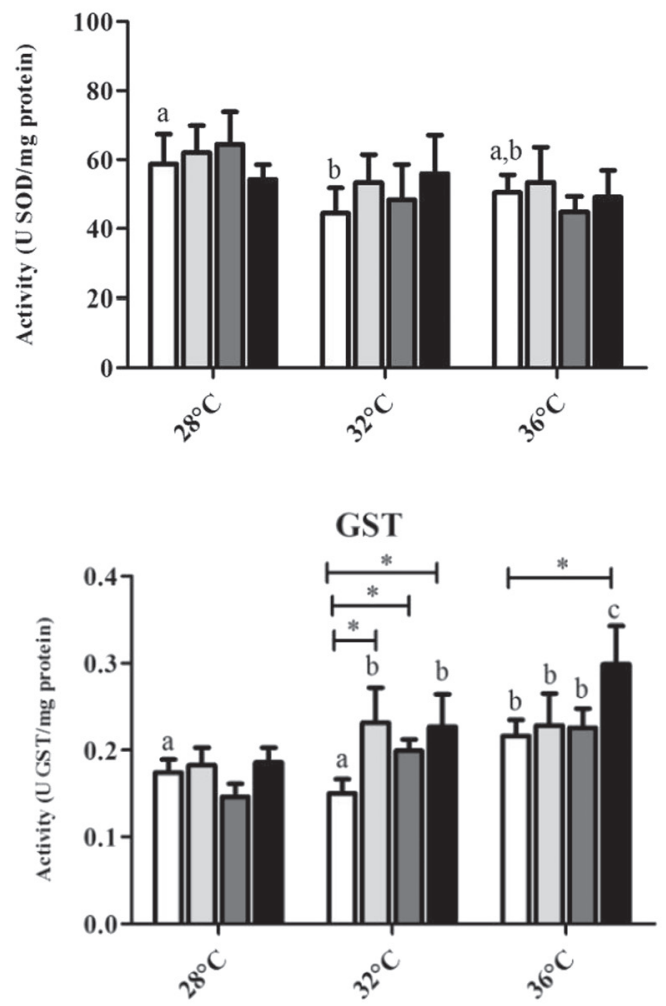

MDA

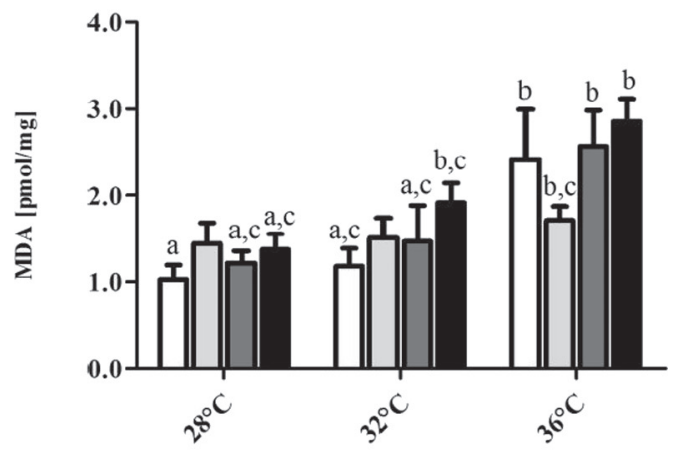

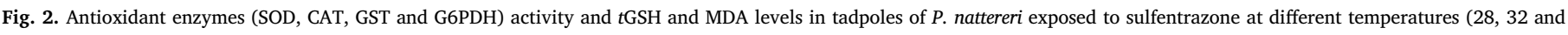

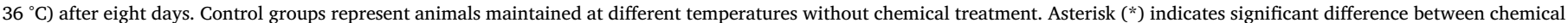
treatments $(0.01,0.05$ and $0.1 \mathrm{mg} / \mathrm{L})$ at the same temperature. Different letters indicate statistical significance $(P<0.05)$ among relevant groups treated at different temperatures.

and $0.1 \mathrm{mg} / \mathrm{L}(P=0.020 ; P=0.0042 ; P=0.00012$, respectively), with a 2.5 -fold increase for the higher concentration. An increase in G6PDH activity was also observed for animals treated at 0.01 and $0.1 \mathrm{mg} / \mathrm{L}$ at $32{ }^{\circ} \mathrm{C}$ compared to control at $28{ }^{\circ} \mathrm{C} \quad(P=0.001$, $P=0.0001$, respectively). Similarly, GST activity was induced by exposure to sulfentrazone in animals treated at all concentrations ( $P=0.00012, P=0.049, P=0.00012$, respectively). An interaction effect of sulfentrazone and temperature also increased GST activity in animals exposed to 0.01 and $0.1 \mathrm{mg} / \mathrm{L}$ at $32{ }^{\circ} \mathrm{C}$ compared to the control at $28{ }^{\circ} \mathrm{C}(P<0.001)$. $t \mathrm{GSH}$ levels were also augmented in tadpoles exposed to the highest concentration at $32{ }^{\circ} \mathrm{C}$ compared to the control at the same temperature $(P=0.009)$. No effects were observed in the activities of SOD or CAT at $32{ }^{\circ} \mathrm{C}(P>0.05)$. At $36{ }^{\circ} \mathrm{C}$, G6PDH had a similar response to that observed in the treatments at $32{ }^{\circ} \mathrm{C}$, with increased activity in animals exposed to all concentrations of sulfentrazone $(P=0.00024, P=0.00017, P=0.00012)$. An interactive effect of sulfentrazone and the higher temperature was detected in the G6PDH activity of animals exposed to $0.1 \mathrm{mg} / \mathrm{L}$ at $36{ }^{\circ} \mathrm{C}$ compared to the control at $28^{\circ} \mathrm{C}(P=0.0001)$. Tadpoles treated with $0.1 \mathrm{mg} / \mathrm{L}$ of sulfentrazone at $36{ }^{\circ} \mathrm{C}$ also had an increase on GST activity compared to 
the control at the same temperature $(P=0.0001)$ and to the control at $28^{\circ} \mathrm{C}(P=0.0001)$, showing evidence for an interaction effect at $36^{\circ} \mathrm{C}$. In contrast to that observed at $32{ }^{\circ} \mathrm{C}, t \mathrm{GSH}$ levels were decreased in animals exposed to $0.05 \mathrm{mg} / \mathrm{L}$ of sulfentrazone at $36{ }^{\circ} \mathrm{C}$ compared to its respective control $(P=0.017)$. Effects of sulfentrazone were not found for SOD or CAT activities at $36^{\circ} \mathrm{C}(P>0.05)$ (Fig. 2).

Lipid peroxidation was induced in tadpoles exposed to sulfentrazone with temperature-dependent responses for both experimental periods in tadpoles of $P$. nattereri (Figs. 1 and 2). Single effects of temperature were also detected in untreated tadpoles. Animals maintained at $32{ }^{\circ} \mathrm{C}$ presented the lowest levels of MDA compared to the control at $28^{\circ} \mathrm{C}$ $(P=0.021)$ and $36{ }^{\circ} \mathrm{C}(P<0.001)$ after three days (Fig. 1$)$. After eight days, untreated animals maintained at $36^{\circ} \mathrm{C}$ had the highest levels of MDA $(P<0.001)$ (Fig. 2).

Tadpoles of $P$. nattereri exposed to 0.05 and $0.1 \mathrm{mg} / \mathrm{L}$ of sulfentrazone at $28{ }^{\circ} \mathrm{C}$ and $32{ }^{\circ} \mathrm{C}$ had increased MDA levels compared to the control groups at the respective temperatures $(P<0.001)$ after three days of exposure (Fig. 1). No changes were found in animals treated at $36^{\circ} \mathrm{C}$, and no interaction effects were detected after three days $(P>0.05)$ (Fig. 1). After eight days, sulfentrazone had no effect on MDA levels at $28{ }^{\circ} \mathrm{C}(P>0.05)$. However, exposure of animals to $0.1 \mathrm{mg} / \mathrm{L}$ at $32{ }^{\circ} \mathrm{C}$ increased the levels of MDA compared to untreated animals at $28{ }^{\circ} \mathrm{C}(P=0.0086)$. Also, interaction effects of sulfentrazone treatments at $36^{\circ} \mathrm{C}$ increased MDA in tadpoles of all groups compared to controls at $28^{\circ} \mathrm{C}(P<0.001)$ (Fig. 2).

IBR index evaluation showed that there was an interaction between the effects of temperature and sulfentrazone for $P$. nattereri tadpoles after three and eight days of exposure $(P<0.001)$ (Fig. 5). After three days, tadpoles exposed to 0.05 and $0.1 \mathrm{mg} / \mathrm{L}$ of sulfentrazone at $28{ }^{\circ} \mathrm{C}$ had the highest IBR $(P<0.001)$, decreasing at 32 and $36^{\circ} \mathrm{C}$, until become similar to other treatments at $36^{\circ} \mathrm{C}(P<0.001)$ (Fig. 5). In addition, IBR of tadpoles exposed to $0.1 \mathrm{mg} / \mathrm{L}$ of sulfentrazone at $32{ }^{\circ} \mathrm{C}$ was higher than the other groups at the same temperature. After eight days of exposure, IBR increased with temperature only in animals exposed to $0.1 \mathrm{mg} / \mathrm{L}$ of sulfentrazone $(P<0.001)$. Tadpoles exposed to the higher concentration of sulfentrazone at 32 and $36^{\circ} \mathrm{C}$ had the highest IBR values $(P<0.02)$ after eight days (Fig. 5).

\subsubsection{R. schneideri}

Single effects of temperature were observed in antioxidant responses of unexposed tadpoles of $R$. schneideri to sulfentrazone (Figs. 3 and 4). After three days, CAT activity was decreased in control animals maintained at $32{ }^{\circ} \mathrm{C}$ and $36^{\circ} \mathrm{C}$ compared to those at $28{ }^{\circ} \mathrm{C}$ $(P<0.001)$. G6PDH was 2 -fold higher in animals maintained at $36{ }^{\circ} \mathrm{C}$ than the control group at $28^{\circ} \mathrm{C}(P=0.012)$. $t \mathrm{GSH}$ also increased 2 -fold in tadpoles of the control group at $36{ }^{\circ} \mathrm{C}(P=0.006)$ (Fig. 3). After eight days, CAT $(P=0.41)$, SOD $(P=0.97)$ and $t \mathrm{GSH}(P=0.54)$ were unchanged by the single effect of temperature; however, G6PDH had a 4.5-fold increase in tadpoles maintained at $36{ }^{\circ} \mathrm{C}$ compared to the control group at $28{ }^{\circ} \mathrm{C}(P<0.001)$. GST activity was higher in control animals at $32{ }^{\circ} \mathrm{C}$ after eight days $(P=0.048)$ (Fig. 4).

The exposure of $R$. schneideri to sulfentrazone for three and eight days promoted changes in enzyme activity with temperature-associated responses (Figs. 3 and 4). Treatments with sulfentrazone at $28{ }^{\circ} \mathrm{C}$ decreased the activities of CAT $(P=0.001)$ and GST $(P=0.041)$ in tadpoles treated with $0.05 \mathrm{mg} / \mathrm{L}$ after three days. CAT was also lower in tadpoles exposed to $0.1 \mathrm{mg} / \mathrm{L}$ than the control group at $28^{\circ} \mathrm{C}$ $(P=0.05)$. G6PDH and $t \mathrm{GSH}$ had no changes after exposure to sulfentrazone at this temperature $(P>0.05)$. Significant temperature-associated increases of G6PDH activity were observed in all groups treated at $32{ }^{\circ} \mathrm{C}$ compared to control animals at the same temperature $(P<0.001)$. Increases up to 4 -fold in G6PDH were also observed as result of an interaction between sulfentrazone and temperature at $32{ }^{\circ} \mathrm{C}$ compared to untreated animals at $28^{\circ} \mathrm{C}(P<0.001)$. SOD activity was increased by the interaction effect of the higher concentration of sulfentrazone at $32{ }^{\circ} \mathrm{C}$ compared to the control at $28^{\circ} \mathrm{C}(P=0.0006)$.
No effects of sulfentrazone on GST $(P=0.9)$, CAT $(P=0.102)$ and tGSH $(P=0.16)$ were observed for treatments at $32{ }^{\circ} \mathrm{C}$ after three days. Treatments at $36{ }^{\circ} \mathrm{C}$ decreased CAT activity in all concentrations compared to the control at $28{ }^{\circ} \mathrm{C}(P<0.001)$. In contrast, SOD and G6PDH activities were increased following exposure to 0.05 and $0.1 \mathrm{mg} / \mathrm{L}$ at $36{ }^{\circ} \mathrm{C}$ compared to the control at $28^{\circ} \mathrm{C}(P<0.01)$. No effects of sulfentrazone were observed on GST and $t \mathrm{GSH}$ at $36^{\circ} \mathrm{C}$ after three days $(P>0.05)$ (Fig. 3).

After eight days of exposure, sulfentrazone treatments at $28{ }^{\circ} \mathrm{C}$ did not alter antioxidant response of the animals, except for $t \mathrm{GSH}$ levels, which were increased in tadpoles exposed to $0.05 \mathrm{mg} / \mathrm{L}(P=0.001)$. The activity of the enzymes CAT, SOD and G6PDH were also not altered following the treatments at $32{ }^{\circ} \mathrm{C}(P>0.05)$. In addition, no differences were observed in $t \mathrm{GSH}$ levels at this temperature $(P>0.05)$. GST was the only enzyme altered by sulfentrazone at $32{ }^{\circ} \mathrm{C}$, with a 1.5 fold decrease in animals exposed to $0.1 \mathrm{mg} / \mathrm{L}(P=0.024)$. Also, animals exposed to $0.01 \mathrm{mg} / \mathrm{L}$ at $32{ }^{\circ} \mathrm{C}$ had higher GST activity than the same treatment at $28{ }^{\circ} \mathrm{C}(P=0.006)$. The highest levels of CAT were observed in tadpoles exposed to all concentrations of sulfentrazone at $36{ }^{\circ} \mathrm{C}$ after eight days. G6PDH activity was decreased in tadpoles treated with 0.05 and $0.1 \mathrm{mg} / \mathrm{L}$ of sulfentrazone at $36^{\circ} \mathrm{C}$ compared to the control at the same temperature $(P=0.002$, $P=0.0001$, respectively). However, the interaction effect of the higher temperature and sulfentrazone promoted a pronounced increase of G6PDH (increases up to 4.5-fold) in comparison to the other treatments at 28 and $32{ }^{\circ} \mathrm{C}(P<0.001)$. SOD, GST and $t$ GSH had no changes after eight days of treatments at $36{ }^{\circ} \mathrm{C}(P>0.05)$ (Fig. 4).

Unlike $P$. nattereri, temperature had no isolated effects on lipid peroxidation in $R$. schneideri tadpoles. Furthermore, exposure to sulfentrazone at any temperature and concentration changed MDA levels in this species $(P>0.05)$ (Figs. 3 and 4$)$.

For the IBR analysis, there was interaction between temperature and sulfentrazone after three days of exposure $(P<0.001)$ in $R$. schneideri (Fig. 5). Overall, there was a trend of IBR increase with the temperature only evident for tadpoles exposed to $0.05 \mathrm{mg} / \mathrm{L}$ of sulfentrazone. No difference was found in IBR among tadpoles exposed to sulfentrazone treatments compared to the control group at $28^{\circ} \mathrm{C}$ (Fig. 5). After eight days, the IBR of tadpoles was influenced only by temperature $(P<0.01)$, with an increasing trend in tadpoles maintained at $36{ }^{\circ} \mathrm{C}$ $(P<0.001)$.

\section{Discussion}

Several environmental variables can directly or indirectly affect the health of organisms in a variety of taxa (Hooper et al., 2013; Moe et al., 2013; Noyes et al., 2009; Tu et al., 2012). Changes in environmental temperatures are of particular concern because they may not only change the toxicity of chemical compounds, but also the physiological responses of cold-blooded organisms and their ability to deal with contaminants in the environment (Hooper et al., 2013) Antioxidant responses are expected to be affected by changes in environmental temperature in these organisms, since heat exposure can dramatically increase ROS production as result of an increased oxygen consumption (Lushchak, 2011). However, there is a lack of data clarifying how antioxidant systems of aquatic organisms may alter with high temperatures in contaminated environments. Amphibians are one of the most vulnerable vertebrate groups to effects of combinations of environmental stressors in their habitats. Surprisingly, studies on amphibians are scarce. In the current study, we showed that antioxidant enzymes in tadpoles of $P$. nattereri and $R$. schneideri had their responses altered by single and combined exposures to sulfentrazone and temperature. Temperature-associated responses of the antioxidant enzymes and MDA levels in tadpoles exposed to sulfentrazone indicate that temperature plays a relevant role in the toxicity of this herbicide in tadpoles of both studied species. The different patterns found in the measured variables in $P$. nattereri and $R$. schneideri are evidenced by the integrated 


\section{R. schneideri $\square 0.01 \mathrm{mg} / \mathrm{L}$ \\ 3 days-exposure $0.05 \mathrm{mg} / \mathrm{L}$}

CAT

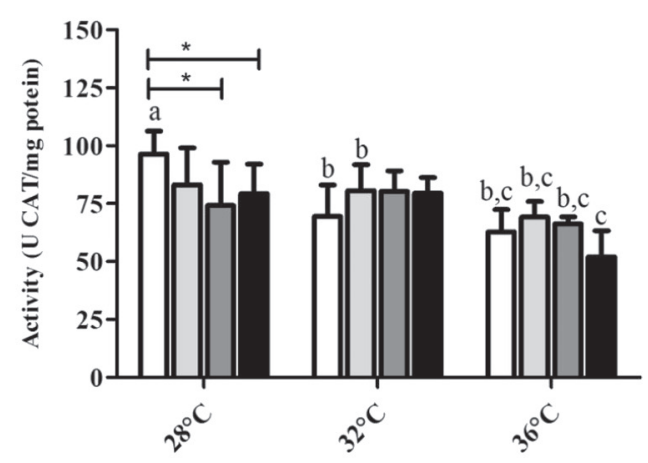

G6PDH

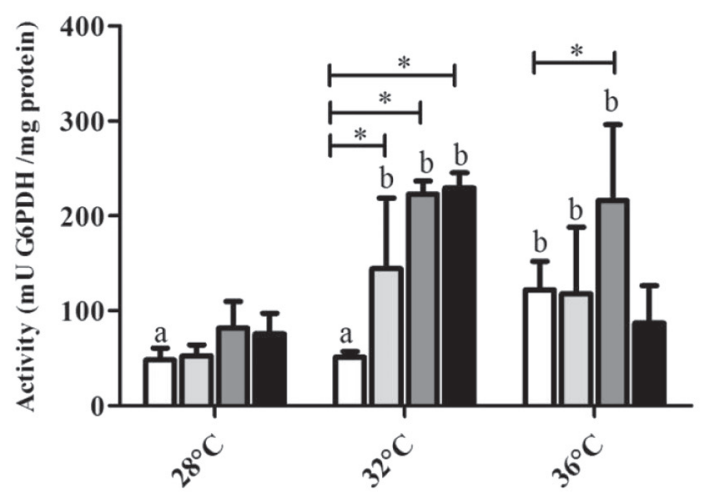

tGSH

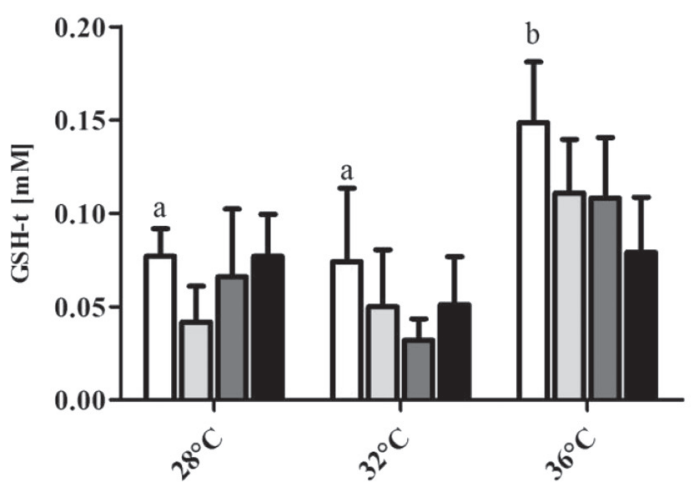

SOD

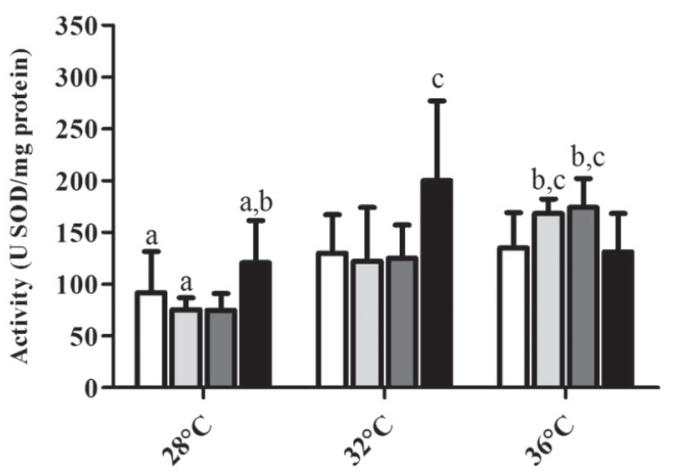

GST

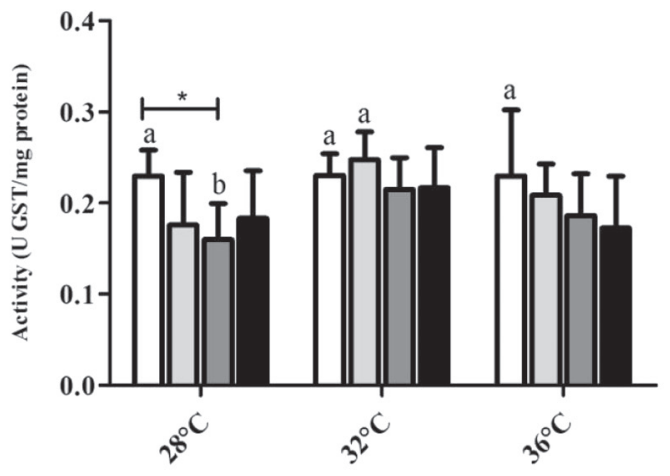

MDA

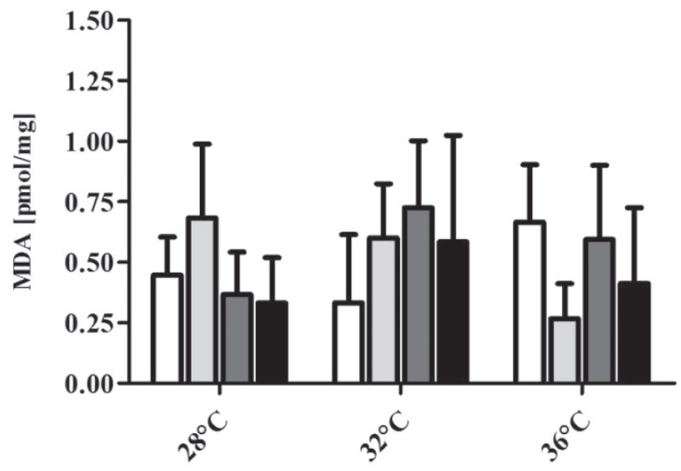

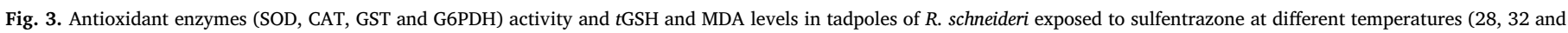

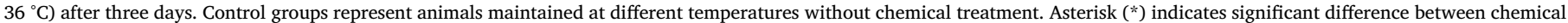
treatments $(0.01,0.05$ and $0.1 \mathrm{mg} / \mathrm{L})$ at the same temperature. Different letters indicate statistical significance $(P<0.05)$ among relevant groups treated at different temperatures.

biomarker response (IBR), with the first species presenting greater sensitivity to both temperature and sulfentrazone. These results support the concept that expression of biomarkers driven by environmental conditions may be species-specific, even for taxonomically related groups. These results associated with previous studies (Gripp et al., 2017; Harley et al., 2006; Lushchak, 2011) suggest that such alterations to antioxidant defence systems are associated with the adaptation mechanisms used by these organisms to deal with increased ROS production in animals exposed to stressful environmental conditions.

Exposure to sulfentrazone caused temporal- and temperature-de- pendent responses in antioxidant enzymes and MDA levels for both species. In tadpoles of $P$. nattereri, sulfentrazone-treated tadpoles presented several alterations on biochemical responses after three days of exposure; however, most of them were more evident at 28 and $32{ }^{\circ} \mathrm{C}$, including increases in MDA levels. On the other hand, sulfentrazone effects were more pronounced at higher temperatures after eight days of exposure, including changes in SOD, G6PDH, GST and $t \mathrm{GSH}$, alongside the evident rise in MDA levels at $36^{\circ} \mathrm{C}$. Besides the individual response of biochemical markers, these effects were also evidenced by the IBR index analysis for both experimental periods in tadpoles of $P$. 


\section{8 days-exposure $\quad 0.05 \mathrm{mg} / \mathrm{L}$}

CAT

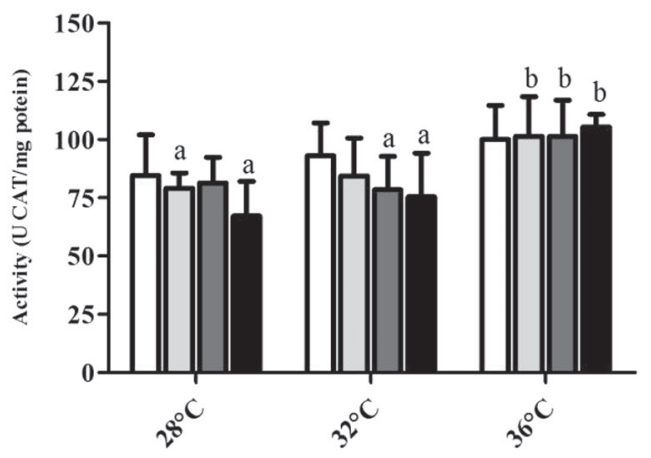

G6PDH

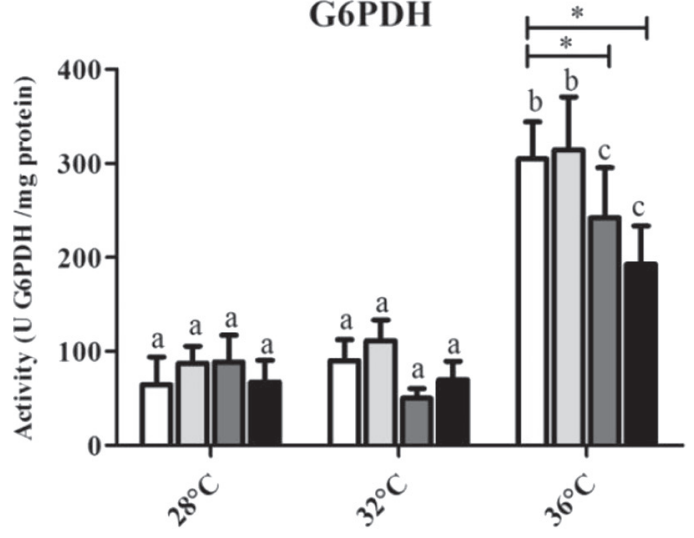

tGSH

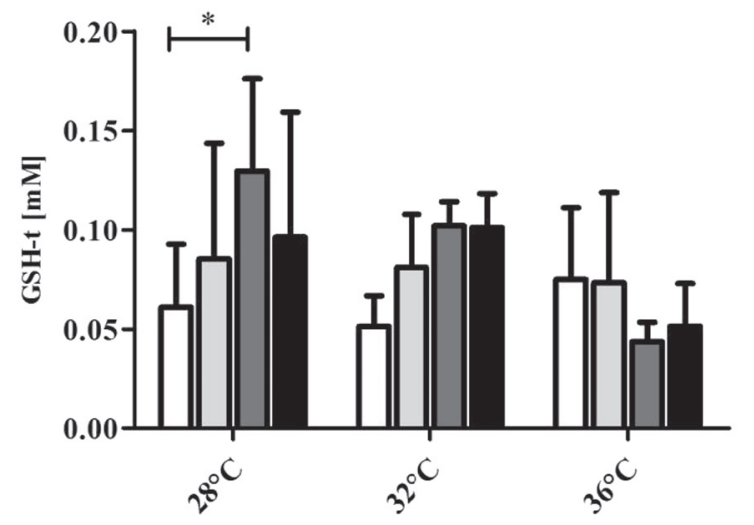

SOD
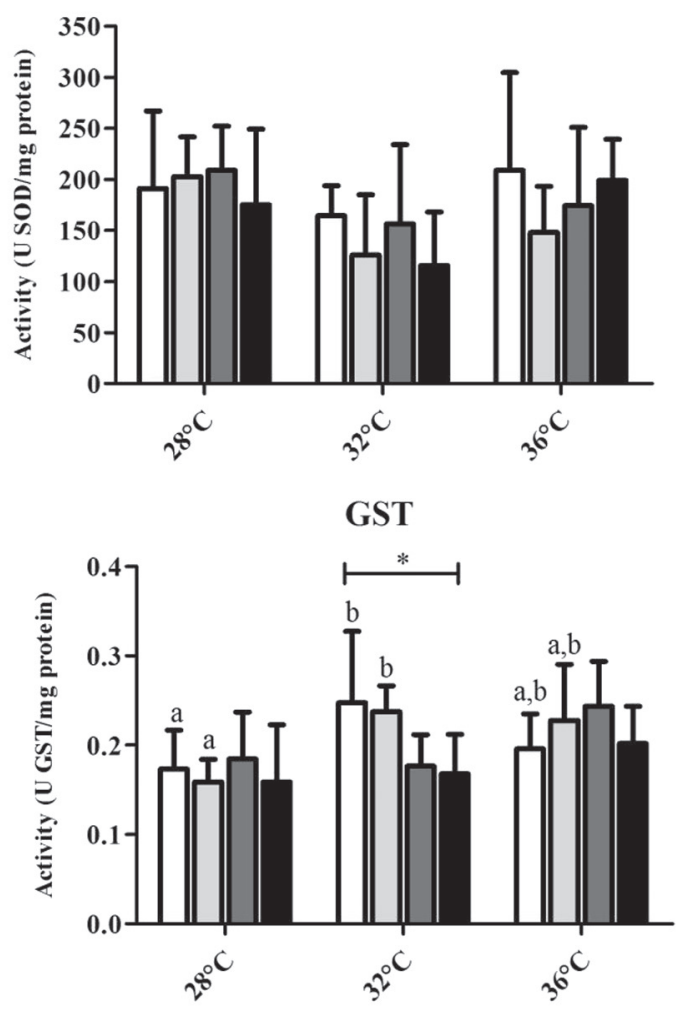

MDA

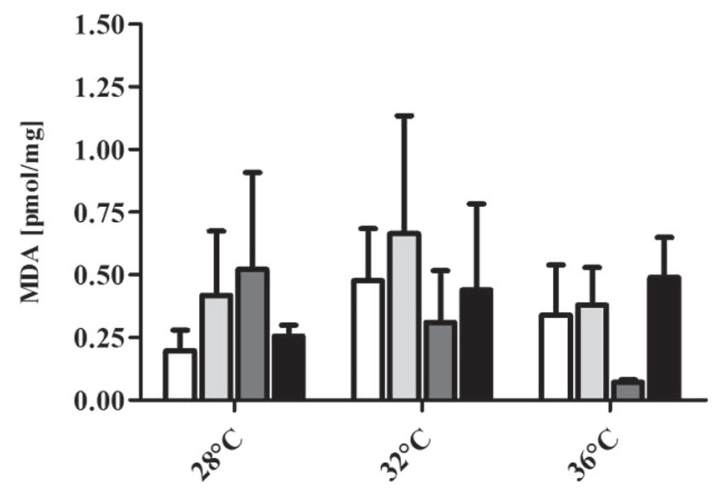

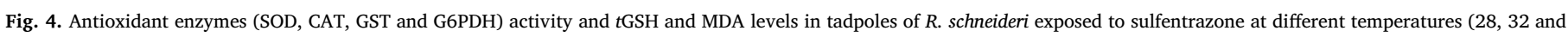

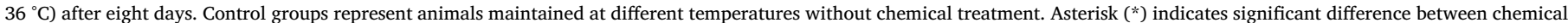

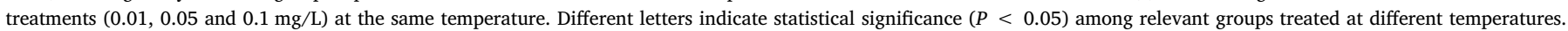

nattereri, especially when associated with the higher concentrations of sulfentrazone. For $R$. schneideri, the responses of some biochemical parameters exhibited different changes compared to $P$. nattereri. In this species, most of the antioxidant enzymes had activities altered after three days of exposure, with more prominent responses at higher temperatures (32 and $36^{\circ} \mathrm{C}$ ). After longer exposure, no alterations were observed at $28^{\circ} \mathrm{C}$, and CAT, SOD and G6PDH had their activities normalized at $32{ }^{\circ} \mathrm{C}$. In addition, no alterations in MDA levels were observed in $R$. schneideri tadpoles after exposure to sulfentrazone at any temperature for both periods. The results observed in P. nattereri and $R$. schneideri in our study showed that the behaviour of antioxidant enzymes in tadpoles exposed to sulfentrazone vary in different species depending on the temperature of exposure. Also, these responses can be varied at different exposure durations, probably due to differential 


\section{$\square$ Control \\ $\square .01 \mathrm{mg} / \mathrm{L}$ \\ Integrated Biomarker Response $\square 0.05 \mathrm{mg} / \mathrm{L}$ \\ (IBR) \\ $0.1 \mathrm{mg} / \mathrm{L}$}
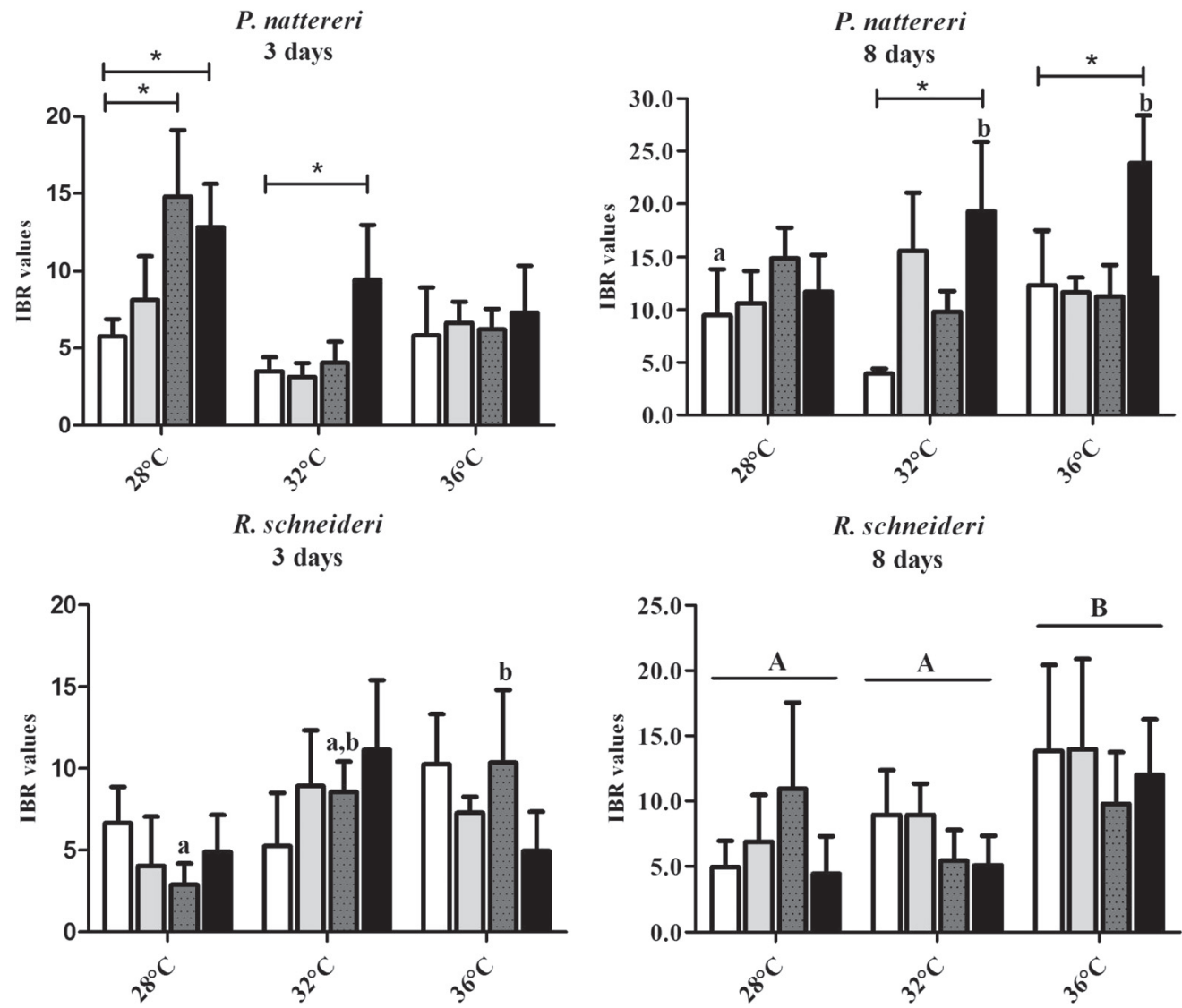

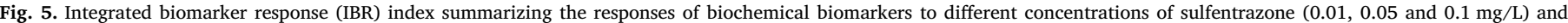

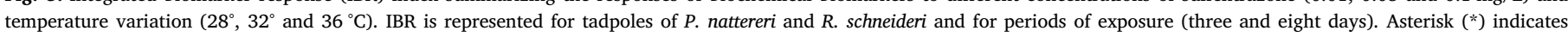

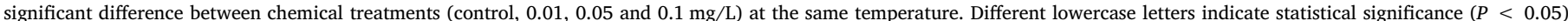

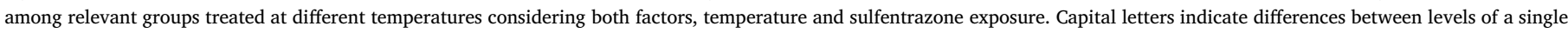
factor (in this case, temperature) and the different letters indicate statistical significance $(P<0.05)$ among different temperature groups.

stimulation of the antioxidant system in an attempt to adapt the animals to such adverse conditions during an extended period. However, varied responses could also be the result of a prolonged effect of the chemical in combination with thermal stress, which could trigger further damage to the antioxidant defence system during an extended period.

Previous studies have shown that interactive effects of heat stress and pesticide exposure may impair the antioxidant defence system of some aquatic animals (Kaur et al., 2011; Tu et al., 2012). For example, the exposure to the insecticide deltamethrin combined to the heat stress treatment caused a significant decrease in the activity of CAT in the liver, kidney and gills, and an increase of GST and glutathione peroxidase (GPx) in the liver and kidney in the saltwater fish Channa punctata (Kaur et al., 2011). Activity of CAT was also decreased in the black tiger shrimp (Penaeus monodon) exposed to deltamethrin at $34^{\circ} \mathrm{C}$ after four days, but not at 24 and $29^{\circ} \mathrm{C}$ (Tu et al., 2012). According to Sekine et al. (1996), increasing or decreasing the temperature can influence toxicity of several pollutants. Synergistic effects of water temperature and herbicides have been reported for some species of fish (Moore and Waring, 2001; Tarja et al., 2003). These integrated effects may impair the antioxidant system, stimulating or inhibiting enzyme activity in specific tissues and organisms. An increase in antioxidant enzyme activity has been reported to be a general response of aquatic organisms, such as fish and amphibians, exposed to environmental contaminants (Gripp et al., 2017; Jones et al., 2010; Peltzer et al., 2013;
Stephensen et al., 2002) as an activation process to neutralize the impacts of ROS (Lopez-Torres et al., 1993). On the other hand, decreases in antioxidant enzymes should occur when the stress condition is exceeding and cannot be compensated by the antioxidant system anymore (Kaur et al., 2011). In agreement with previous studies, the variation in antioxidant responses observed in tadpoles exposed to sulfentrazone at different thermal gradients confirms that temperature is an important factor influencing the activity of many antioxidant enzymes in aquatic organisms exposed to environmental contaminants. This could in turn affect all physiological functions and the ability of these animals to adapt to adverse conditions. These results are especially relevant for amphibians, since, until now, there has been no information on how the integrated effects of chemicals and temperatures could affect these biochemical parameters for different species.

G6PDH and GST activity were the most evident biomarkers jointly affected by sulfentrazone and thermal stress. G6PDH activity was notably altered in tadpoles exposed to sulfentrazone at higher temperatures, with a pronounced increase for both species. G6PDH is an important cytosolic enzyme that participates in the first step of the pentose phosphate pathway, maintaining the levels of NADPH in the cells (Kletzien et al., 1994). NADPH in turn reduces oxidized glutathione (GSSG) in glutathione (GSH), which is an important tripeptide that protects cells against oxidative damage (De Almeida et al., 2011). 
Thus, cells with decreased G6PDH may be especially sensitive to oxidative stress. Previous studies with $P$. nattereri have shown that G6PDH activity was increased in tadpoles exposed to a metabolite of the insecticide fipronil (fipronil sulfide) after seven days (Gripp et al., 2017). In our study, G6PDH activity was not only increased by sulfentrazone treatment, but also by the interaction effects of chemical and heat stress. This is probably due to an increased demand of NADPH in the cells in an attempt to reduce oxidant effects caused by these combined stress conditions. Conversely, depletion of G6PDH was observed in tadpoles of $R$. schneideri exposed to higher concentrations of sulfentrazone at $36{ }^{\circ} \mathrm{C}$ after eight days when compared to the control at the same temperature. This behaviour of G6PDH in tadpoles of $R$. schneideri is probably a result of the intensified effect generated at $36^{\circ} \mathrm{C}$, which was not compensated by the increased activity of this enzyme. It could impair other antioxidant NADPH-dependent factors, leading organisms to have greater vulnerability to dealing with environmental stressors.

$t \mathrm{GSH}$ levels were also modulated following treatments with sulfentrazone at different temperatures for both species. Glutathione (GSH) is the predominant nonprotein sulfhydryl in cells and is also an integral part of the antioxidant system (De Almeida et al., 2011; Pastore et al., 2003; Sies, 2003). GSH content has been mentioned as a protective mechanism that aquatic organisms adopt in the initial phases of exposure to xenobiotics (Stephensen et al., 2002). It is a primordial electron donor in reductive processes for synthesis and degradation of proteins, formation of deoxyribonucleotides and for reduction of $\mathrm{H}_{2} \mathrm{O}_{2}$ and organic peroxides (De Almeida et al., 2011). GSH contents have been shown as a relevant biomarker in studies evaluating the combined effects of temperature and chemical exposure for aquatic organisms. Fish (Channa punctata) pre-exposed to deltamethrin followed by heat stress had an increase in the GSH content in the liver and a decrease in the gills, indicating the different vulnerability of different tissues to the toxicants (Kaur et al., 2011). Higher $t \mathrm{GSH}$ levels were also reported in gills and hepatopancreas in the marine shrimp Penaeus monodon exposed to deltamethrin at the highest tested temperature $\left(34^{\circ} \mathrm{C}\right)$ than those at $29^{\circ} \mathrm{C}$ and $24^{\circ} \mathrm{C}$ (Tu et al., 2012). The black rockfish Sebastes schlegeli exposed to cooper also presented higher levels of $t \mathrm{GSH}$ in different tissues when maintained at elevated temperatures (Min et al., 2014). In our study, the $t \mathrm{GSH}$ content had a temperature-associated response in tadpoles of $P$. nattereri and $R$. schneideri, with differential behaviour for different periods of exposure. These varied responses could be in part due to the different needs of tadpoles in dealing with an oxidative stress induced by adverse conditions of temperature and chemical exposure in a pathway using GSH as a co-factor in the antioxidant response. Changes in GSH levels may also interfere in the formation of conjugates between glutathione and exogenous compounds in a reaction catalysed by glutathione-S-transferases (Boyland and Chasseaud, 1969), which is an essential aspect on the metabolism of xenobiotics. Increased rates of conjugate reaction, as part of the chemical metabolism, could lead to GSH depletion in the cells, increasing susceptibility to lipid peroxidation and oxidative stress (De Almeida et al., 2011).

MDA levels were only increased in $P$. nattereri following the treatments with sulfentrazone and temperature, suggesting that lipid peroxidation was particularly induced in this species. The isolated effect of temperature also changed the levels of MDA in tadpoles of $P$. nattereri. Indeed, thermal stress has been reported to induce lipid peroxidation in fish (Chien and Hwang, 2001; Parihar et al., 1997), which is also evident in the findings of the present study. However, these effects can be enhanced when thermal stress is combined to chemical exposure, as observed previously in the fish Channa punctata exposed deltamethrin at different temperatures (Kaur et al., 2011). In our study, sulfentrazone-exposed tadpoles had lipid peroxidation induced in animals treated with higher concentrations at 28 and $32{ }^{\circ} \mathrm{C}$ after three days. After eight days, MDA was higher in all groups treated at $36^{\circ} \mathrm{C}$, suggesting that sulfentrazone effects could be masked by heat effects in $P$. nattereri, since lipid peroxidation had already been stimulated by temperature in longer exposures. Lipid peroxidation has been previously reported in different species of tadpoles exposed to several pesticides such as fipronil, atrazine, glyphosate and quinclorac (Dornelles and Oliveira, 2014; Gripp et al., 2017). However, data available in the literature do not clarify how temperature fluctuations and consequently thermal stress in natural systems can potentiate damage on lipid membranes by exposure to pesticides. Lipid peroxidation is considered a major negative effect of oxidative stress as a consequence of excessive ROS generation in cells (Ojha et al., 2011). Increased levels of MDA in tadpoles of $P$. nattereri exposed to sulfentrazone and thermal stress indicates an oxidative stress condition for this species resulting from the exposure of animals to both interaction effects and temperature effects only.

While the detected changes on individual biomarkers provided insights on biochemical mechanisms involved in the response to temperature and chemicals, the variable behaviour and specificity of each biomarker make the perception of the general biological response trends a difficult task. By using an integrative approach, as the IBR in our case (Beliaeff and Burgeot, 2002), we provided a straightforward way to summarize the influence of the explanatory variables on the tadpoles. Overall, the IBR results indicate that $P$. nattereri tadpoles are influenced by both temperature and sulfentrazone. Warmer environments combined to higher concentrations of sulfentrazone and longer exposures are associated with the greatest alterations in the biomarkers, suggesting a synergic effect of temperature and sulfentrazone for this species. However, the variation in IBR was shown to be influenced mainly by the temperature in tadpoles of $R$. schneideri. In fact, the index probably was influenced by the lack of alterations in MDA levels, added to the antioxidant responses, which were normalized after longer exposure to contaminants, suggesting that $R$. schneideri may be less sensitive to the stress generated by sulfentrazone in the field. These results are of great relevance in monitoring studies of amphibian populations in South America and may support some explanations on the status attributed to $P$. nattereri, which presents the current population trend designed as decreasing and its main threats has been pointed to the spread of intensive agriculture in the Cerrado biome (Stuart et al., 2008).

Acceleration of development was observed in tadpoles of $P$. nattereri exposed to $0.05 \mathrm{mg} / \mathrm{L}$ of sulfentrazone at $32{ }^{\circ} \mathrm{C}$ after eight days of exposure. No alterations in metamorphosis were observed in tadpoles of $R$. schneideri for either period. Amphibian larvae have the ability to accelerate metamorphosis in response to deteriorating conditions in the environment, such as the presence of chemicals, as well as alterations of temperature (Brande-lavridsen et al., 2010; Morand et al., 1997; Murata and Yamauchi, 2005; Peltzer et al., 2013). Exposure to elevated temperatures usually reduces the time needed to complete metamorphosis for many amphibian species (Morand et al., 1997). This mechanism can provide benefits for the species, such as escaping mortality or toxic effects of contaminated habitats. However, it may also incur costs, such as reduced juvenile and adult survival, alterations to physiological performance and higher vulnerability to external predators (Denver et al., 1998; Goater et al., 2016; Smith, 1987). Although changes in development have not been observed in the other tested experimental conditions for $P$. nattereri and $R$. schneideri, it is reasonable to expect developmental alterations if tadpoles are exposed to higher concentrations or longer periods of exposure, which were not addressed in the present study.

\section{Conclusions}

In summary, we found that temperature can alter the toxic effects of sulfentrazone on certain biochemical biomarkers, importantly impairing antioxidant defence and causing oxidative stress in tadpoles. Differential activation of the antioxidant system in $P$. nattereri and $R$. schneideri suggests that tadpoles of different species may use diverse 
strategies and adaptive mechanisms to cope with the effects generated by exposure to agrochemicals in habitats where the temperature is a relevant influencing factor. The efficiency of the antioxidant mechanisms is crucial for the health of these organisms, since the imbalance in ROS content can cause several negative consequences, such as damage to cellular constituents and regulation of cellular process, impairing adaptation to internal and environmental changes. Such alterations could in turn result in extensive consequences at population levels, and this is particularly worrying for native species in Brazil, where tadpoles usually experience large temperature fluctuations in their habitats. In an environmental monitoring perspective, the results based on the integrated approach highlight that the effects of sulfentrazone combined to thermal stress could be assessed more predictably by using $P$. nattereri tadpoles as bioindicators. Furthermore, given the highly variable results of sulfentrazone at different temperatures and in different species, it is clear that more studies need to be conducted to establish a general consensus of the impacts of thermal stress in the toxicity of this and other pesticides on amphibians.

\section{Acknowledgments}

This work was supported by the "Conselho Nacional de Desenvolvimento Científico e Tecnológico" (CNPq, Brazil, 473245/ 2009-4). J.S.F. was supported by a doctoral fellowship from "Fundação de Amparo à Pesquisa do Estado de São Paulo" (FAPESP, Brazil, grant no. 2013/16948-3) and F.B.T. by CNPq, Brazil (grant no. 302158/20154). E.A.A. is a recipient of the CNPq productivity fellowship.

\section{Appendix A. Supplementary data}

Supplementary data to this article can be found online at http://dx. doi.org/10.1016/j.cbpc.2017.04.005.

\section{References}

Almeida, E.A., 2003. Avaliação de Variações Bioquímicas em Moluscos bivalves em Resposta ao Estresse Ambiente. (Ph.D. thesis) Universidade de São Paulo - Instituto de Química, São Paulo, Brasil.

Bagnyukova, T.V., Storey, K.B., Lushchak, V.I., 2003. Induction of oxidative stress in Rana ridibunda during recovery from winter hibernation. J. Therm. Biol. 28, 21-28. http:// dx.doi.org/10.1016/S0306-4565(02)00031-1.

Bao, V.W.W., Koutsaftis, A., Leung, K.M.Y., 2008. Temperature-dependent toxicities of chlorothalonil and copper pyrithione to the marine copepod Tigriopus japonicus and dinoflagellate Pyrocystis lunula. Australas. J. Ecotoxicol. 14, 45-54.

Beliaeff, B., Burgeot, T., 2002. Integrated biomarker response: a useful tool for ecological risk assessment. Environ. Toxicol. Chem. 21, 1316.

Beutler, E., 1975. Red Cell Metabolism: A Manual of Biochemical Methods. Grune \& Stratton, New York.

Bernarde, P.S., Kokubum, M.N.D.C., 1999. Anurofauna do município de Guararapes, Estado de São Paulo, Brasil (Amphibia: Anura). Acta Biol. Leopoldensia.

Blaustein, A.R., Kiesecker, J.M., 2002. Complexity in conservation: lessons from the global decline of amphibian populations. Ecol. Lett. 5, 597-608. http://dx.doi.org/ 10.1046/j.1461-0248.2002.00352.x.

Blaustein, A.R., Walls, S.C., Bancroft, B.A., Lawler, J.J., Searle, C.L., Gervasi, S.S., 2010. Direct and indirect effects of climate change on amphibian populations. Diversity 2, 281-313. http://dx.doi.org/10.3390/d2020281.

Boone, M.D., Bridges, C.M., 1999. The effect of temperature on the potency of carbaryl for survival of tadpoles of the green frog (Rana clamitans). Environ. Toxicol. Chem. 18, 1482-1484. http://dx.doi.org/10.1002/etc.5620180720.

Boyland, E., Chasseaud, L.F., 1969. The Role of Glutathione and Glutathione STransferases in Mercapturic Acid Biosynthesis. Adv. Enzymol. Relat. Areas Mol. Biol. $32,173-219$.

Bradford, M.M., 1976. A rapid and sensitive method for the quantitation of microgram quantities of protein utilizing the principle of protein-dye binding. Anal. Biochem. 72, 248-254.

Brande-lavridsen, N., Christensen-dalsgaard, J., Korsgaard, B., 2010. Effects of Ethinylestradiol and the fungicide Prochloraz on metamorphosis and thyroid gland morphology in Rana temporaria. Open Zool. 3, 7-16. http://dx.doi.org/10.2174/ 1874336601003010007.

Chien, L.T., Hwang, D.F., 2001. Effects of thermal stress and vitamin C on lipid peroxidation and fatty acid composition in the liver of thornfish Terapon jarbua. Comp. Biochem. Physiol. B Biochem. Mol. Biol. 128, 91-97. http://dx.doi.org/10. 1016/S1096-4959(00)00299-2.

Dayan, F.E., Watson, S.B., 2011. Plant cell membrane as a marker for light-dependent and light-independent herbicide mechanisms of action. Pestic. Biochem. Physiol. 101,
$182-190$.

De Almeida, E.A., Humberto Silva, D.G., Dias Bainy, A.C., Freitas, F.P., Motta, F.D., Gomes, O.F., Gennari De Medeiros, M.H., Di Mascio, P., 2011. Evaluation of glutathione status in aquatic organisms. Oxidative Stress Aquat. Ecosyst. 381-388. http://dx.doi.org/10.1002/9781444345988.ch28.

Denver, R., Mirhadi, N., Phillips, M., 1998. Adaptive plasticity in amphibian metamorphosis: responses of Scaphiopus hammondii tadpoles to habitat desiccation. Ecology 79, 1859-1873. http://dx.doi.org/10.1890/0012-9658(1998) 079[1859:APIAMR]2.0.CO;2.

Devin, S., Burgeot, T., Giambérini, L., Minguez, L., Pain-Devin, S., 2014. The integrated biomarker response revisited: optimization to avoid misuse. Environ. Sci. Pollut. Res. 21 (4), 2448-2454. http://dx.doi.org/10.1007/s11356-013-2169-9.

Dornelles, M.F., Oliveira, G.T., 2014. Effect of atrazine, glyphosate and quinclorac on biochemical parameters, lipid peroxidation and survival in bullfrog tadpoles (Lithobates catesbeianus). Arch. Environ. Contam. Toxicol. 66, 415-429. http://dx.doi. org/10.1007/s00244-013-9967-4.

Dutra De Armas, E., Rosim Monteiro, R.T., Valler Amâncio, A., Lopes Correa, R.M., Guercio, M.A., 2005. Uso de agrotóxicos em cana-de-açúcar na bacia do rio Corumbataí e o risco de poluição hídrica. Quim Nova 28, 975-982. http://dx.doi. org/10.1590/S0100-40422005000600008.

Egea-Serrano, A., Relyea, R.A., Tejedo, M., Torralva, M., 2012. Understanding of the impact of chemicals on amphibians: a meta-analytic review. Ecol. Evol. 2, 1382-1397. http://dx.doi.org/10.1002/ece3.249.

Embrapa, 2013. Empresa Brasileira de Pesquisa Agropecuária. Plantas Daninhas. Disponível em: http://www.agencia.cnptia.embrapa.br/gestor/cana-de-acucar/ arvore/CONTAG01_52_711200516718.

Fontenot, C.L., Lutterschmidt, W.I., 2011. Thermal selection and temperature preference of the aquatic salamander, Amphiuma tridactylum. Herpetol. Conserv. Biol. 6, 395-399.

Freitas, J.S., Kupsco, A.J., Diamante, G., Felicio, A.A., Alves de Almeida, E., Schlenk, D., 2016. Influence of temperature on the thyroidogenic effects of Diuron and its metabolite 3,4-DCA in tadpoles of the American bullfrog (Lithobates catesbeianus). Environ. Sci. Technol.. http://dx.doi.org/10.1021/acs.est.6b04076. (acs.est. 6b04076).

Gatten, R.E., Miller, K, Full, R.J., 1992. Energetics at rest and during locomotion. In: Feder, M.E., Burggren, W.W. (Eds.), Environmental Physiology of the Amphibians. University of Chicago Press, Chicago, pp. 314-377.

Glock, G.E., McLean, P., 1953. Further studies on the properties and assay of glucose 6 phosphate dehydrogenase and 6-phosphogluconate dehydrogenase of rat liver. Biochem. J. 55, 400-408.

Goater, C.P., Semlitsch, R.D., Bernasconi, M.V., Goater, C.P., Semlitsch, R.D., Bernasconi, M.V., 2016. Nordic Society Oikos Effects of Body Size and Parasite Infection on the Locomotory Performance of Juvenile Toads, Bufo bufo. Wiley on behalf of Nordic Society Oikos Stablepp. 129-136(URL: http://www.jstor.org/stable/3545205 REFERENCES Linked referenc 66).

Gosner, K., 1960. A simplified table for staging anuran embryos and larvae with notes on identification. Herpetologica 16, 183-190.

Greulich, K., Pflugmacher, S., 2003. Differences in susceptibility of various life stages of amphibians to pesticide exposure. Aquat. Toxicol. 65, 329-336. http://dx.doi.org/ 10.1016/S0166-445X(03)00153-X.

Gripp, H.S., Freitas, J.S., Almeida, E.A., Bisinoti, M.C., Moreira, A.B., 2017. Biochemical effects of fipronil and its metabolites on lipid peroxidation and enzymatic antioxidant defense in tadpoles (Eupemphix nattereri: Leiuperidae). Ecotoxicol. Environ. Saf. 136, 173-179. http://dx.doi.org/10.1016/j.ecoenv.2016.10.027.

Habig, W.H., Pabst, M.J., Jakoby, W.B., 1974. Glutathione S-transferases. The first enzymatic step in mercapturic acid formation. J. Biol. Chem. 249, 7130-7139.

Hammond, S.A., Veldhoen, N., Helbing, C.C., 2015. Influence of temperature on thyroid hormone signaling and endocrine disruptor action in Rana (Lithobates) catesbeiana tadpoles. Gen. Comp. Endocrinol. 219, 6-15. http://dx.doi.org/10.1016/j.ygcen. 2014.12.001.

Harley, C.D.G., Hughes, A.R., Hultgren, K.M., Miner, B.G., Sorte, C.J.B., Thornber, C.S., Rodriguez, L.F., Tomanek, L., Williams, S.L., 2006. The impacts of climate change in coastal marine systems. Ecol. Lett. 9, 228-241. http://dx.doi.org/10.1111/j.14610248.2005.00871.x.

Hatzios, K.K., 1998. Supplement to Herbicide Handbook, seventh ed. Weed Science Society of Americapp. 67-69.

Hirata, S., 2010. Lixiviação e persistência dos herbicidas sulfentrazone e imazapic leaching and persistence of Sulfentrazone and Imazapic. 28, 185-195. http://dx.doi. org/10.1590/S0100-83582010000100022.

Hooper, M.J., Ankley, G.T., Cristol, D.A., Maryoung, L.A., Noyes, P.D., Pinkerton, K.E., 2013. Interactions between chemical and climate stressors: a role for mechanistic toxicology in assessing climate change risks. Environ. Toxicol. Chem. 32, 32-48. http://dx.doi.org/10.1002/etc.2043.

IPT Instituto de Pesquisas tecnológicas do estado de São Paulo, 2000. Diagnóstico da situação atual dos recursos hídricos e estabelecimento de diretrizes técnicas para a elaboração do plano da Bacia de São José dos Dourados e Relatório número 40675 e Minuta. CR Room.

Jones, L., Gossett, D., Banks, S., McCallum, M., 2010. Antioxidant defense system in tadpoles of the American bullfrog (Lithobates catesbeianus) exposed to paraquat. J. Herpetol. 44, 222-228. http://dx.doi.org/10.1670/07-243.1.

Katzenberger, M., Tejedo, M., Duarte, H., Marangoni, F., Beltrán, J.F., 2012. Tolerância e sensibilidade térmica em anfíbios. Rev. Biol. 8, 25-32. http://dx.doi.org/10.7594/ revbio.08.05.

Kaur, M., Atif, F., Ansari, R.A., Ahmad, F., Raisuddin, S., 2011. The interactive effect of elevated temperature on deltamethrin-induced biochemical stress responses in Channa punctata Bloch. Chem. Biol. Interact. 193, 216-224. http://dx.doi.org/10. 
1016/j.cbi.2011.06.011.

Kletzien, R.F., Harris, P.K., Foellmi, L.A., 1994. Glucose-6-phosphate dehydrogenase: a "housekeeping" enzyme subject to tissue-specific regulation by hormones, nutrients, and oxidant stress. FASEB J. 8, 174-181.

Lopez-Torres, M., Perez-Campo, R., Cadenas, S., Rojas, C., Barja, G., 1993. A comparative study of free radicals in vertebrates-2. Nonenzymatic antioxidants and oxidative stress. Comp. Biochem. Physiol. B Biochem. Mol. Biol. 105, 757-763.

Lushchak, V.I., 2011. Environmentally induced oxidative stress in aquatic animals. Aquat. Toxicol. 101, 13-30. http://dx.doi.org/10.1016/j.aquatox.2010.10.006.

Madeira, D., Narciso, L., Cabral, H.N., Vinagre, C., Diniz, M.S., 2013. Influence of temperature in thermal and oxidative stress responses in estuarine fish. Comp. Biochem. Physiol. A Mol. Integr. Physiol. 166, 237-243. http://dx.doi.org/10.1016/j. cbpa.2013.06.008.

Martinez, C.O., Silva, C.M.M.S., Fay, E.F., Abakerli, R.B., Maia, A.H.N., Durrant, L.R 2010. Microbial degradation of sulfentrazone in a Brazilian rhodic hapludox soil. Braz. J. Microbiol. 41, 209-217. http://dx.doi.org/10.1590/S1517. 83822010000100030 .

Mcdiarmid, Roy.W, Altig, R., 1999. Tadpoles: The Biology of Anuran Larvae. McDiarmid, Altig, Chicago.

Melo, C., Medeiros, W., Tuffi Santos, L.D., FERREIRA, F., Ferreira, G., Paes, F.A.S.V., Reis, M.R., 2010. Residual effect of sulfentrazone, isoxaflutole and oxyfluorfen in three soils. Planta Daninha 28, 835-842.

Middlebrooks, E.J., Gaspar, M.J., Gaspar, R.D., Reynolds, J.H., 1973. Effects of Temperature on the Toxicity to the Aquatic Biota of Waste Discharges - A Compilation of the Literature.

Min, E., Baeck, S., Kang, J.-C., 2014. Combined effects of copper and temperature on Hematological constituents in the Rock fish, Sebastes schlegeli. J. Fish Pathol. 27, 57-65. http://dx.doi.org/10.7847/jfp.2014.27.1.057.

Moe, S.J., De Schamphelaere, K., Clements, W.H., Sorensen, M.T., Van den Brink, P.J., Liess, M., 2013. Combined and interactive effects of global climate change and toxicants on populations and communities. Environ. Toxicol. Chem. 32, 49-61. http://dx.doi.org/10.1002/etc. 2045.

Moore, A., Waring, C.P., 2001. The effects of a synthetic pyrethroid pesticide on some aspects of reproduction in Atlantic salmon (Salmo salar L.). Aquat. Toxicol. 52, 1-12. http://dx.doi.org/10.1016/S0166-445X(00)00133-8.

Morand, A., Joly, P., Grolet, O., 1997. Phenotypic variation in metamorphosis in five anuran species along a gradient of stream influence. C. R. Acad. Sci. III 320, 645-652. http://dx.doi.org/10.1016/S0764-4469(97)85698-3.

Murata, T., Yamauchi, K., 2005. Low-temperature arrest of the triiodothyroninedependent transcription in Rana catesbeiana red blood cells. Endocrinology 146, 256-264. http://dx.doi.org/10.1210/en.2004-1090.

Noyes, P.D., McElwee, M.K., Miller, H.D., Clark, B.W., Van Tiem, L.A., Walcott, K.C., Erwin, K.N., Levin, E.D., 2009. The toxicology of climate change: environmental contaminants in a warming world. Environ. Int. 35, 971-986. http://dx.doi.org/10 1016/j.envint.2009.02.006.

Ojha, A., Yaduvanshi, S.K., Srivastava, N., 2011. Effect of combined exposure of commonly used organophosphate pesticides on lipid peroxidation and antioxidant enzymes in rat tissues. Pestic. Biochem. Physiol. 99, 148-156. http://dx.doi.org/10. 1016/j.pestbp.2010.11.011.

Parihar, M.S., Javeri, T., Hemnani, T., Dubey, A.K., Prakash, P., 1997. Responses of superoxide dismutase, glutathione peroxidase and reduced glutathione antioxidant defenses in gills of the freshwater catfish (Heteropneustes fossilis) to short-term elevated temperature. J. Therm. Biol. 22, 151-156. http://dx.doi.org/10.1016/ S0306-4565(97)00006-5.

Pastore, A., Federici, G., Bertini, E., Piemonte, F., 2003. Analysis of glutathione: implication in redox and detoxification. Clin. Chim. Acta 333, 19-39. http://dx.doi. org/10.1016/S0009-8981(03)00200-6.

Peltzer, P.M., Lajmanovich, R.C., Attademo, A.M., Junges, C.M., Cabagna-Zenklusen, M.C., Repetti, M.R., Sigrist, M.E., Beldoménico, H., 2013. Effect of exposure to contaminated pond sediments on survival, development, and enzyme and blood biomarkers in veined treefrog (Trachycephalus typhonius) tadpoles. Ecotoxicol. Environ. Saf. 98, 142-151. http://dx.doi.org/10.1016/j.ecoenv.2013.09.010.

Prado, V.H.M. Do, Borges, R.E., Silva, F.R. Da, Tognolo, T.T., Rossa-Feres, D.D.C., 2008 Amphibia, Anura, Hylidae, Phyllomedusa azurea: distribution extension. Check List 4, $55-56$.

Provete, D.B., Garey, M.V., Silva, F.R. Da, Rossa-Feres, D.D.C., 2011. Anurofauna do noroeste paulista: lista de espécies e chave de identificação para adultos. Biota Neotropical 11, 377-391. http://dx.doi.org/10.1590/S1676-06032011000200036.
R Development Core Team, 2010. R: a language and environment for statistical computing. R Foundation for Statistical Computing, Vienna, Austria Available at: www.r-project.org.

Relyea, R.A., 2005. The lethal impacts of roundup and predatory stress on six species of North American tadpoles. Arch. Environ. Contam. Toxicol. 48, 351-357. http://dx. doi.org/10.1007/s00244-004-0086-0.

Rohr, J.R., Palmer, B.D., 2005. Aquatic herbicide exposure increases salamander desiccation risk eight months later in a terrestrial environment. Environ. Toxicol. Chem. 24, 34.

Rome, L.C., 2007. The effect of temperature and thermal acclimation on the sustainable performance of swimming scup. Philos. Trans. R. Soc. Lond. Ser. B Biol. Sci. 362, 1995-2016. http://dx.doi.org/10.1098/rstb.2007.2083.

Schiedek, D., Sundelin, B., Readman, J.W., Macdonald, R.W., 2007. Interactions between climate change and contaminants. Mar. Pollut. Bull. 54, 1845-1856. http://dx.doi. org/10.1016/j.marpolbul.2007.09.020.

Sekine, M., Nakanishi, H., Ukita, M., 1996. Study on fish mortality caused by the combined effects of pesticides and changes in environmental conditions. Pyridaphenthi $\sim 86,259-264$.

Shinn, C., Marco, A., Serrano, L., 2008. Inter- and intra-specific variation on sensitivity of larval amphibians to nitrite. Chemosphere 71, 507-514. http://dx.doi.org/10.1016/ j.chemosphere.2007.09.054.

Sies, H., 2003. Assay of glutathioine glutathione disulfide and glutathione miced disulfides in biological samples. 77, 10.

Smith, D.C., 1987. Adult recruitment in chorus frogs: effects of size and date at metamorphosis. Ecology 68, 344-350. http://dx.doi.org/10.2307/1939265.

Snodgrass, J.W., Casey, R.E., Joseph, D., Simon, J.A., 2008. Microcosm investigations of stormwater pond sediment toxicity to embryonic and larval amphibians: variation in sensitivity among species. Environ. Pollut. 154, 291-297. http://dx.doi.org/10. 1016/j.envpol.2007.10.003.

Sokal, R., R.J., 1995. Biometry: The Principles and Practices of Statistics in Biological Research: New York.

Stefani Margarido, T.C., Felício, A.A., de Cerqueira Rossa-Feres, D., Alves de Almeida, E., 2013. Biochemical biomarkers in Scinax fuscovarius tadpoles exposed to a commercial formulation of the pesticide fipronil. Mar. Environ. Res. 91, 61-67. http://dx.doi.org/ 10.1016/j.marenvres.2013.02.001.

Stephensen, E., Sturve, J., Förlin, L., 2002. Effects of redox cycling compounds on glutathione content and activity of glutathione-related enzymes in rainbow trout liver. Comp. Biochem. Physiol. C Toxicol. Pharmacol. 133, 435-442. http://dx.doi. org/10.1016/S1532-0456(02)00129-1.

Stuart, S., Hoffmann, M., Chanson, J., Cox, N., Berridge, R., Ramani, P., Young, B., 2008. Threatened Amphibians of the World. Lynx Edicions, IUCN, and Conservation International, Barcelona, Spain; Gland, Switzerland; and Arlington, Virginia, USA

Tarja, N., Kirsti, E., Marja, L., Kari, E., 2003. Thermal and metabolic factors affecting bioaccumulation of triazine herbicides by rainbow trout (Oncorhynchus mykiss). Environ. Toxicol. 18, 219-226. http://dx.doi.org/10.1002/tox.10118.

Thorngren, J.L., Harwood, A.D., Murphy, T.M., Huff Hartz, K.E., Fung, C.Y., Lydy, M.J., 2016. Fate and risk of atrazine and sulfentrazone to non-target species at an agriculture site. Environ. Toxicol. Chem.. http://dx.doi.org/10.1002/etc.3664. (n/a$\mathrm{n} / \mathrm{a})$.

Tietze, F., 1969. Enzymic method for quantitative determination of nanogram amounts of total and oxidized glutathione: applications to mammalian blood and other tissues. Anal. Biochem. 27, 502-522. http://dx.doi.org/10.1016/0003-2697(69)90064-5.

Tu, H.T., Silvestre, F., Meulder, B. De, Thome, J.P., Phuong, N.T., Kestemont, P., Thi, H., Silvestre, F., Meulder, B. De, Thome, J.P., Thanh, N., Kestemont, P., 2012. Combined effects of deltamethrin, temperature and salinity on oxidative stress biomarkers and acetylcholinesterase activity in the black tiger shrimp (Penaeus monodon). Chemosphere 86, 83-91. http://dx.doi.org/10.1016/j.chemosphere.2011.09.022.

UNICA, 2015. União da industria da Cana-de-açucar (2012). Unicadata. http://www. unicadata.com.br.

Vinagre, C., Madeira, D., Narciso, L., Cabral, H.N., Diniz, M., 2012. Effect of temperature on oxidative stress in fish: lipid peroxidation and catalase activity in the muscle of juvenile seabass, Dicentrarchus labrax. Ecol. Indic. 23, 274-279. http://dx.doi.org/10. 1016/j.ecolind.2012.04.009.

Yan, D., Jiang, X., Xu, S., Wang, L., Bian, Y., Yu, G., 2008. Quantitative structure-toxicity relationship study of lethal concentration to tadpole (Bufo vulgaris formosus) for organophosphorous pesticides. Chemosphere 71, 1809-1815. http://dx.doi.org/10. 1016/j. chemosphere.2008.02.033.

Zar, J.H., 1999. Biostatistical Analysis. Prentice Hall. 